\title{
SERİ MUHAKEME USULÜNÜN ADİL YARGILANMA HAKKI VE DİĞER BAZI ANAYASAL İLKELER AÇISINDAN DEĞERLENDİRILLMESİ
}

THE EVALUATION OF THE SERIAL PROCEDURE IN TERMS OF THE RIGHT TO A FAIR TRIAL AND SOME OTHER CONSTITUTIONAL PRINCIPLES

Hakemli Makale

Hakan KARAKEHYA* Asuman İNCE TUNÇER**

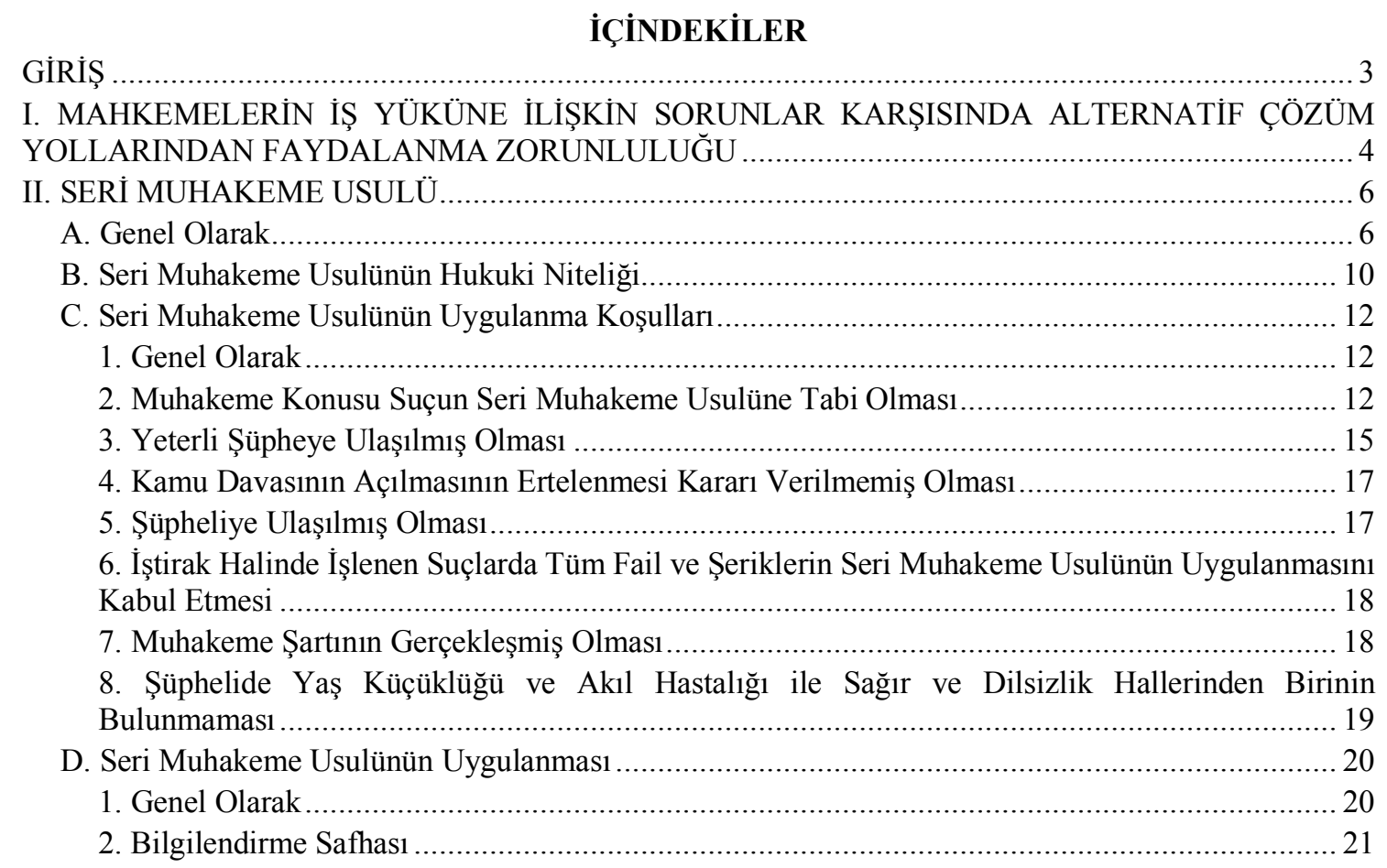

DOI: $10.32957 /$ hacettepehdf. 835957

Makalenin Geliş Tarihi: 04.12.2020

Makalenin Kabul Tarihi: 09.05.2021

* Prof. Dr. Anadolu Üniversitesi Hukuk Fakültesi Ceza ve Ceza Muhakemesi Hukuku Anabilim Dalı. Eposta: hkarakehya@anadolu.edu.tr

ORCID: 0000-0001-5028-1216

** $\quad$ Dr. Öğr. Üyesi. Anadolu Üniversitesi Hukuk Fakültesi Ceza ve Ceza Muhakemesi Hukuku Anabilim Dal1. E-posta: asumanince@anadolu.edu.tr

ORCID: 0000-0003-0454-5262

Bu makale Hacettepe Üniversitesi Hukuk Fakültesi Dergisi Araştırma ve Yayın Etiği kurallarına uygun olarak hazırlanmıştır. 


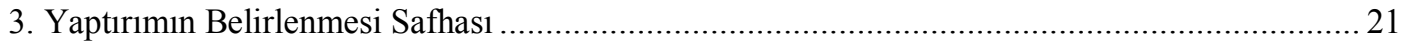

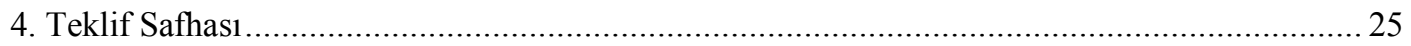

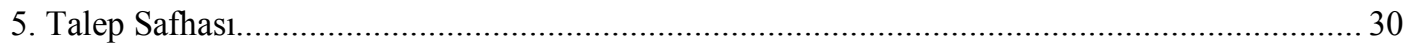

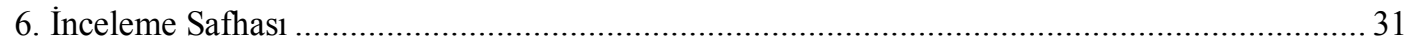

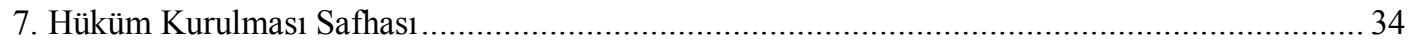

8. Kanun Yolu Safhası........................................................................................................... 34

E. Seri Muhakeme Usulüne İlişkin Belge ve Beyanlara Özgü Delil Değerlendirme Yasağı............... 36

III. GENEL OLARAK ADİL YARGILANMA HAKKI ......................................................... 37

IV. AİHM İÇTİHATLARI IŞIĞINDA ALTERNATİF ÇÖZÜM YOLLARININ ADİL YARGILANMA İLKESINE AYKIRILIĞI SORUNU .................................................................................... 41

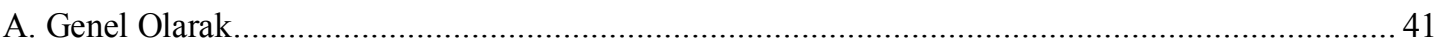

B. Alternatif Çözüm Yolunun İsnat Altındaki Kimsenin Adil Yargılanma Hakkını İhlal Etmemiş Kabul

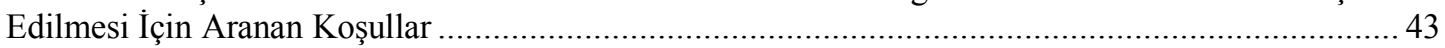

V. SERİ MUHAKEME USULÜNE İLISSTIN DÜZENLEMELERDE, ADİL YARGILANMA HAKKI VE

DİĞER BAZI ANAYASAL İLKELER BAKIMINDAN TESPİT EDİLEN SORUNLAR ................... 47

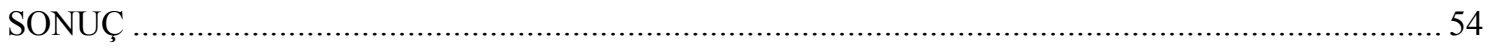

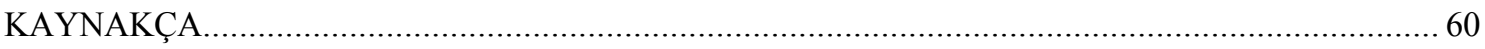

\section{ÖZ}

Birçok gelişmiş devletin hukuk sistemi bakımından yargılamaların uzunluğu ciddi bir sorundur. Bu bağlamda kanun koyucular, birçok hukuki uyuşmazlığı alternatif çözüm yollarıyla çözüme kavuşturma ve böylelikle yargı organlarının iş yükünü azaltma eğilimindedir. Yargı organlarının iş yükünün azalması hem mevcut davaların daha kısa sürede hem de daha iyi inceleme yapılarak sonuçlanmasına imkan verecektir. Kanun koyucumuz da bu amaçla iki yeni muhakeme usulü ihdas etmiştir. Ceza muhakemesi sistemimize, 2019 yılında, 7188 sayılı Kanun’la giren iki önemli kurumdan biri de seri muhakemedir. İstisnai ve sıra dış1 uygulamaları bünyesinde barındıran bu kurum, doktrinde ciddi tartışmaları da beraberinde getirmiştir. Seri muhakemenin özellikle adil yargılanma hakkı bakımından ciddi sorunlar bünyesinde barındırdığı ileri sürülmektedir. Mahkemelerin iş yükünü azaltmak ve muhakemeyi hızlandırmak amacıyla hüküm altına alınan bu usul, bireylere muhakeme hukuku alanında tanınan haklara ciddi şekilde müdahalede bulunmaktadır. Bu müdahalelerin adil yargılanma hakkı ve bazı anayasal ilkeler açısından makul görülüp görülmeyeceği oldukça çetrefilli bir konudur. Çalışmamızda seri muhakeme usulünün adil yargılanma hakkı ve diğer bazı anayasal ilkeler açısından değerlendirmesi yapılmıştır. Bu bağlamda öncelikle seri muhakeme usulüne ilişkin genel tespitlerde bulunulmuş, sonrasında ise adil yargılanma hakkının gerekleri ortaya konulmuştur. Son olarak da bu yeni kurumun adil yargılanma hakkı ve diğer bazı anayasal ilkeler bakımından ihlallere neden olup olmadığı tespit edilmiştir.

Anahtar Sözcükler: seri muhakeme, adil yargılanma hakkı, alternatif çözüm yolları, özel yargılama usulleri, ceza muhakemesi hukuku 


\begin{abstract}
The length of proceedings is a serious problem in terms of the legal systems of many developed states. In this context, legislators tend to resolve many legal disputes with alternative solutions, thereby reducing the workload of judicial bodies. For these purposes, one of the two new special procedures introduced into the Turkish criminal procedure system in 2019 with Law No. 7188 is serial procedure. Incorporating exceptional and extraordinary practices, this institution brought serious discussions in the doctrine. It is alleged that serial procedure has serious problems, especially in terms of the right to a fair trial. This procedure seriously interferes with the rights granted to individuals in the field of procedural law. Whether these interventions are considered reasonable in terms of the right to a fair trial and certain constitutional principles is a highly complex issue. In the study, the serial procedure has been evaluated in terms of the right to a fair trial and some other constitutional principles. In this context, firstly, the general determinations regarding the serial procedure were made, and then the requirements of the right to a fair trial were put forward. Finally, it was determined whether this new procedure caused violations in terms of the right to a fair trial and some other constitutional principles.
\end{abstract}

Keywords: serial procedure, right to a fair trial, alternative solutions, special procedures, criminal procedure law

\title{
GİRIŞ
}

Mahkemelerin iş yükünü azaltmaya yönelik birçok alternatif çözüm yöntemine hukuk sistemimiz içerisinde yer verilmiştir. Önödeme, uzlaşma, kamu davasının açılmasının ertelenmesi, hükmün açıklanmasının geri bırakılması bunlara örnek olarak verilebilir. 2019 yılında yapılan kanun değişikliği ile bu kurumlara eklenen yeni alternatif çözüm yollarından biri de seri muhakemedir. Diğer alternatif çözüm yollarında olduğu gibi bu yeni muhakeme kurumu da mahkemelerin iş yükünü azaltmayı, böylelikle mahkemelerin ellerindeki diğer dosyalara daha fazla vakit ayırarak, bunlarla ilgili uyuşmazlıkları daha çabuk çözüme kavuşturmalarını amaçlamaktadır. Bu sayede ceza davalısı kişilerin makul sürede yargılanma hakkı da ihlal edilmemiş olacaktır.

Bununla birlikte söz konusu usulün uygulanması bakımından, sanığın adil yargılanma hakkına ilişkin birçok güvenceden ve anayasal haktan feragat etmesi gerekmektedir. Bu bağlamda söz konusu usulün Anayasaya ve Türkiye'nin taraf olduğu uluslararası sözleşmelere uygun olup olmadığına ilişkin ciddi tartışmalar bulunmaktadır. Ancak birçok demokratik devlette gözlendiği üzere, mahkemelerin iş yükünün fazlalığı, 
modern ceza muhakemesinin birçok temel ilkesine istisna getirilerek, bu tür alternatif cezai uyuşmazlık çözüm yollarının ihdasını zorunlu kılmaktadır. Elbette ki bu tür kurumlara ilişkin olarak hiç kimse, gönül rahatlığı ile sorunsuz bir sistem öngörüldüğünü söyleyememektedir. Nitekim alternatif çözüm yollarının birçok farklı türü vardır ve bunlardan her birinin muhakemenin temel ilkelerinden bazılarını bir yönüyle zedelediği de aşikardır. Ancak ceza adaleti politikası bakımından alınacak kararlarda artı-eksi analizi yapmak gerekir. Çoğu kez bu alandaki politika tercihleri, sosyal hayatın birçok başka alanında olduğu üzere, saf olumlu ya da saf olumsuz (beyaz ya da siyah) sonuçlar vermez. Daha çok gri renklerin ağırlıkta olduğu görülür. Dolayısıyla muhakeme hukuku bakımından bu yeni kurumların da getirisi ve götürüsünün ne olduğuna bakmak gerekir.

Ayrıca belirtmek gerekir ki; her ne kadar ciddi ihtiyaç olsa da bu tür kurumların hukuk devletinin bir gereği olarak anayasal sınırlar içerisinde hükme bağlanması zorunluluktur. Bu nedenle seri muhakemenin de adil yargılanma hakkı ve diğer anayasal ilkeler açısından daha ayrıntılı ele alınması gerekir. Çalışmamızda, söz konusu kurumun adil yargılanma hakkı ve diğer anayasal ilkeler bakımından detaylı bir değerlendirilmesi yapılacaktır. Bu bağlamda öncelikle mahkemelerin iş yoğunluğu karşısında alternatif çözüm yollarından faydalanma zorunluluğu ve seri muhakeme usulüne ilişkin açıklamalar yapılacak, daha sonra adil yargılanma hakkına ilişsin temel bilgiler verilecek, son olarak da seri muhakeme usulünün adil yargılanma hakkı ve diğer bazı anayasal ilkelere ilişkin değerlendirmesi yapılacaktır.

\section{MAHKEMELERIN IŞ YÜKÜNE İLIŞKIIN SORUNLAR KARŞISINDA ALTERNATIF ÇÖZÜM YOLLARINDAN FAYDALANMA ZORUNLULUĞU}

Uyuşmazlığın niteliğine uygun olarak makul bir sürede yargılanmak sanık bakımından adil yargılanmanın en önemli gereklerindendir ${ }^{1}$. Adaletin makul bir sürede sağlanması özellikle masum kimselerin yargılandığı durumlarda bir an önce itibarlarının

YENISEY, Feridun, "Ceza Adaleti Sisteminin Etkinliği, Normal Çalışma Süresi ve Gecikme”, Yeni Türkiye Dergisi, Y1l: 1996, Cilt: 10 Sayı: 2, s.575. 
iadesi edilmesini sağlar ${ }^{2}$. Öte yandan adaletin sürate feda edilmemesi de gerekir. Bu nedenle salt muhakemeyi çabuklaştırmak amacıyla adil yargılanmaya ilişkin ilkelerden vazgeçilemez ${ }^{3}$. Adil yargılanma ve makul sürede yargılanma ilkeleri arasında bir denge gözetilmelidir.

Adaletin gecikmesi ve muhakemenin çabuklaştırılamaması sorunu sadece Türkiye bakımından geçerli bir sorun değildir. Bugün bazı batılı devletler de dahil olmak üzere bir çok devlette yargılamanın hızlandırılamaması en çok şikayet edilen adli konuların başında gelmektedir ${ }^{4}$. Bu nedenle birçok devlet, modern ceza muhakemesinin bir takım temel ilkelerini zedeleyen kurumlar ihdas ederek muhakeme faaliyetlerini hızlandırmaya çalışmaktadırlar ${ }^{5}$.

Gerçekten de mahkemeler iş yükü altında o kadar çok ezilmektedirler ki; ellerindeki bitirmek için fazlasıyla gayret ettiklerinde hakkıyla yargılama yapmaktan, hakkıyla yargılama yaptıklarında ise birçok kez makul sürede yargılama gerçekleştirmekten

2 TOROSLU, Nevzat, "Ceza Yargılamalarının Çabuklaştırılması Sorunu”, Yeni Türkiye Dergisi, Yı1: 1996, Cilt: 10 Say1: 2, s.613.

3 Geciken adaletin bireysel, toplumsal etkileri, masrafları öteden beri vurgulanmaktadır. Buna karşıllk ceza adaletinin yerine getirilmesinde gecikmenin gerçekten bir problem teşkil etmediği hususunda görüşler de vardır. Nitekim gecikmenin karar verecek olanlara daha fazla düşünme imkanı sağlayacağı, böylece kararların daha isabetli ve nitelikli ve bazı hallerde sanık bakımından faydalı olacağı, gecikmenin zamanaşımının gerçekleşmesine sebebiyet verebileceği, sanığın savunma haklarına saygı gösterilmesinin zorunlu olarak gecikmeyi sonuçlayabileceği öne sürülmüştür. Ancak hiç kuşku yoktur ki, geciken hükümler ceza adalet sistemine olan güveni azaltacak, ülkemizde misallerine rastlandığı üzere, adaletin yerine getirilmesini bizzat suç mağdurları veya yandaşları sağlamaya çalışacaklardır. Zira halk olsun, suçu işlediği iddia olunan sanık olsun veya olaydan doğrudan etkilenen mağdur olsun, kendilerini bir yanından ilgilendiren suç olayının süratle neticelendirilmesi hakkına sahiptirler. AİHM kararlarında da vurgulandığg üzere, gecikme masumun üzerine atılan iddiadan kurtulmasını geciktiriyor ve 1stırabının sürüp gitmesine neden oluyor. Ayrıca müeyyidenin uygulanmasının ertelenmesi sonucunu doğurmakta; bu ise cezanın gerek özel gerekse genel önleme etkisini giderek azaltmaktadır. Bkz. DÖNMEZER, Sulhi / YENISEY, Feridun, Ceza Muhakemesi Hukuku, Beta Yayınevi, İstanbul, 2000, s. 1309.

4 DÖNMEZER, Sulhi, “Ceza Adaleti Sistemimiz Üzerine Düşünceler”, Yeni Türkiye Dergisi, Y1l: 1996, Cilt: 10 Sayı: 2, s. 556.

5 Bu yeni kurumların önemli bir kısmı, şüpheli veya sanığa para cezası gibi bazı yükümlülükler getirerek muhakemeye son verme yolunu açmaktadır. Bu kurumların kabul edilmesinin temel nedenlerinden bir tanesi mahkemelerin iş yükünü azaltmak olduğundan, bu yollara başvurulabilmesi için sanığın suçluluğun tam olarak ispatlanmış olması gerekmez. Bu itibarla nispeten hafif ceza gerektiren suçlar bakımından kabul edilen bu kurumlarda da kişiye belirli cezai yaptırımlar uygulanmakta, ancak onun suçluluğunun ispatı şartı aranmamaktadır. $\mathrm{Bu}$ nedenle bazı yazarlarca bu kurumların ceza muhakemesinin temel ilkelerine ters düştüğü ileri sürülmektedir. Bkz. SCHROEDER, FriedrichChristian, "Ceza Muhakemesinde Fair Trial İlkesi”, Ceza Muhakemesinde Fair Trial İlkesi, İstanbul Barosu Yayını, İstanbul, 1999, s. 46. 
feragat etmeleri gerekmektedir. Bu nedenle alternatif bazı çözüm yolları ile en azından kamusal önemi çok yüksek olmayan cezai uyuşmazlıklar bakımından, bunları mahkeme önüne gelmeden çözüme kavuşturmanın yollarını aramak elzem görünmektedir. Aksi takdirde sistemin giderek daha çok yavaşlamasının ve sonuçta çalışamaz hale gelmesinin önüne geçilemeyecektir.

Alternatif çözüm yolları, mahkemelerin giderek artan iş yükünden kaynaklı nedenlerle oluşan zorunluluğa bağlı olarak ortaya çıkmış kurumlardır. Ancak adil yargılanma hakkı ve diğer bazı temel hakları ciddi şekilde zedeleyen bu tür kurumlara uygulama alanı tanınırken, dikkat edilmesi gereken birtakım kriterler vardır.

\section{SERİ MUHAKEME USULÜ}

\section{A. Genel Olarak}

Ceza Muhakemesi Kanunu'nda (CMK), 2019 yılında yapılan değişikliklerle birlikte hukuk sistemimize giren alternatif cezai uyuşmazlık çözüm yöntemlerinden biri seri muhakeme usulüdür. Seri muhakeme usulü; savcı ile şüphelinin kanunda belirtilen usulle anlaşmaları esasına dayanan, kanunda tahdidi olarak sayılan suçlara ilişkin muhakemeleri çabuklaştırmayı ve böylelikle mahkemelerin iş yükünü azaltmayı amaçlayan özel bir muhakeme türüdür ${ }^{6}$. Kanun koyucu bu usulle, mahkemelerin iş

6 Benzer yönde bkz. “... kanun koyucunun bu yöntemin ceza muhakemesi ve yargllaması işlemlerinden farklı ve kendine özgü bir yöntem olarak kabul ettiği anlaşılmaktadır.” YAVUZ, Hakan A., Ceza Muhakemesinde Kovuşturmaya Alternatif Yöntemler, Adalet Yayınevi, Ankara, 2020, s. 248. “...seri muhakeme usulü soruşturma evresine ilişkin bir düzenleme olup, iddianamenin düzenlenmesi yerine, görevli mahkemeye hitaben seri muhakeme talep yazısının (talepname) düzenlendiği, Cumhuriyet savcısının, bu yazıda belirlediği cezai yaptırıma temel aldığı delilleri göstermek zorunda olmadığ (CMK m. 250/8), kural olarak hakimin yetkisinde olan hapis cezasının ertelenmesi (TCK m. 51), seçenek yaptırımlara çevrilmesi (TCK m. 50) ve hükmün açıklanmasının geri bırakılması (CMK m. 231) kurumlarının da Cumhuriyet savcısl tarafindan belirlenebildiği sui generis bir kurumdur." YILMAZ, Zahit / APİş, Özge, "Seri Muhakeme ve Basit Yargılama Düzenlemelerinin Değerlendirilmesi”, Marmara Üniversitesi Hukuk Fakültesi Hukuk Araştırmaları Dergisi, Yıl: 2020, Cilt: 26 Sayı: 1, s. 64. İstisnai ve özel bir yarg1lama usulü olduğu yönünde bkz. KEZER, 2019, Ahmet, 30 Soru ve Yanıtta Seri Muhakeme Usulü ve Basit Yargılama Usulü, Adalet Yayınevi, Ankara, 2019, s. 38. “...gerek soruşturmaya gerekse kovuşturmaya ilişkin ilkeleri bünyesinde barındıran seri muhakeme usulünün CMK'nın soruşturma ve kovuşturma evrelerinin kurallarını içeren kendine özgü bir usul olduğunu söylemek mümkündür.” Bkz. TAŞKIN, Ş. Cankat, Ceza Muhakemesi Hukukunda Seri Muhakeme ve Basit Yargılama Usulü, Adalet Yayınevi, Ankara, 2020, s. 20 vd. 
yükünü azaltmayı ve adil yargılanma hakkı kapsamında yer alan alt haklardan olan makul sürede yargılanma hakkını bireyler bakımından teminat altına almayı amaçlamıştır. Nitekim seri muhakeme usulünün uygulanması suretiyle bazı uyuşmazlıklar bakımından ilk derece mahkemelerinin ve dolayısıyla kanun yolu mercilerinin iş yükü azaltılacaktır. Böylelikle söz konusu merciler ellerinde olan diğer davalara daha çok vakit ayırabilecek ve bunları da daha kısa sürede adil biçimde çözüme kavuşturabileceklerdir ${ }^{7}$.

Seri muhakeme usulü uygulamasının, isnat altındaki kimseyi, adil yargılanma hakkı kapsamında yer alan duruşmaya çıkma, aleni yargılanma ve suçsuzluk karinesinden faydalanma gibi diğer birçok haktan mahrum ettiği de tartışmasızdır. Ancak birçok demokratik devlette gözlendiği üzere, mahkemelerin iş yükünün fazlalığı, modern ceza muhakemesinin birçok temel ilkesine istisna getirilerek, bu tür alternatif cezai uyuşmazlık çözüm yollarının ihdasını zorunlu kılmaktadır ${ }^{8}$. Bununla birlikte, uygulamada ciddi bir ihtiyaç bulunsa da bu tür kurumların hukuk devletinin bir gereği olarak anayasal sınırlar içerisinde hükme bağlanması zorunluluktur.

7188 sayılı Kanun'un gerekçesinde Alman CMK'nın “Mahkeme ile muhakeme süjeleri arasında uzlaşma" başlıklı 257/c maddesi örnek olarak gösterilmiştir. Ancak söz konusu düzenleme incelendiğinde; mahkeme ile muhakeme süjeleri arasındaki uzlaşmanın duruşma esnasında gerçekleşebileceği, uygulanabilmesi için ikrarın zorunlu olduğu; uzlaşma içeriğinin mahkeme ve muhakeme süjeleri arasında bir müzakere ile belirlendiği ve sanık ile savcılığın kabul etmesi halinde uzlaşmanın meydana geldiği görülmektedir. Ayrıca mahkemenin uzlaşma sonrasında hukuki veya maddi açıdan

7 Aynı yönde bkz. ERDEM, Mustafa Ruhan / ŞENTÜRK, Candide, "Ceza Muhakemesi Hukukunda Yeni Bir Kurum Olarak Seri Muhakeme Yöntemi”, Ceza Hukuku Dergisi, Y1l: 2019, Cilt: 14, Sayı, 41, s. 575; ŞAHIN, Cumhur / GÖKTÜRK, Neslihan, Ceza Muhakemesi Hukuku II, Seçkin Yayınevi, Ankara, 2020, s. 203. Çeşitli dünya ülkelerinde uygulanan alternatif uyuşmazlık çözüm yöntemlerine ilişkin bkz. ÖZBEK, Mustafa, "Dünya Capındaki Adalete Ulaşma Hareketleriyle Gelişmeler ve Alternatif Uyuşmazlık Çözümü”, Ankara Üniversitesi Hukuk Fakültesi Dergisi, Yı1: 2002, Cilt: 51, Say1: 2, (s. 121 - 162).

8 Benzer değerlendirmeler için bkz. DEĞİRMENCİ, Olgun, "Ceza Muhakemesi Hukukunda Seri Muhakeme Usulü”, Ankara Batı Adliyesi Dergisi, Yıl:2020, Sayı: Ocak-Haziran, s. 16 vd.; KIZILARSLAN, 2019, Hakan, "7188 Say1lı Kanun'la Ceza Muhakemesi Hukukuna Getirilen Seri Muhakeme ve Basit Yargılama Usulleri”, Bahçeşehir Üniversitesi Hukuk Fakültesi Dergisi, Yıl: 2019, Cilt: 14, Sayı:183 - 184, s. 1895-1896. 
önemli olan hususlar dikkate alınmamış yahut bunlar daha sonra ortaya çıkmışsa, önerilen cezanın fiil ve kusura uygun olmadığı kanaatine varırsa uzlaşma sona ermektedir (Alman CMK m. 257/c/4). Söz konusu uzlaşma uygulaması kovuşturma aşamasında gerçekleşmekte ve mahkeme tarafından hüküm kurulmaktadır. Sanığın cezasında belli oranda indirime gidilmesi şeklinde bir zorunluluk ise öngörülmemiştir. Oysa seri muhakeme usulü soruşturma aşamasında gerçekleşmekte, şüphelinin ikrarı aranmamakta $^{9}$, ceza savcı tarafindan belirlenerek yarısı oranında indirilmekte ve mahkeme yalnızca şekli bir inceleme yaparak hükmü onaylamaktadır. Ayrıca Almanya örneğinin aksine kurulan hüküm istinafa tabi değildirr ${ }^{10}$. İtiraz kanun yolu öngörülmüştür. Almanya örneğinde şüphelinin kabulünün aranmasının ceza yargılamasının maddi gerçeği arama amacından bir sapma mahiyetinde olan bu kurumun uygulanabilmesinin bir koşulu olarak görüldüğü anlaşılmaktadır. Tüm bu nedenlerle doktrinde de haklı olarak belirtildiği gibi seri muhakeme usulünün çok esaslı noktalarda yukarıda sözünü ettiğimiz yöntemden farklılaştı̆̆ını söylemek gerekir ${ }^{11}$.

Esasen seri muhakeme usulü, Alman CMK'nın 407. maddesi ile özel bir muhakeme usulü olarak düzenlenen ceza kararnamesiyle daha benzer nitelikler göstermektedir. Nitekim kurumun hukuki niteliğine ilişkin olarak doktrinde, seri muhakeme usulünün yargılamasız ceza olmaz ilkesinin bir istisnası olan ceza kararnamesi türlerinden biri

9 Bir görüşe göre; seri muhakeme usulü savcıllğın iddianame tanzim etmeden şüphelinin suçlamayı kabul etmesi halinde mahkeme tarafından olası alacağı cezanın yarısının teklif edildiği bir usuldür. Bkz. KEZER, 2019, 2019, s. 38. Seri muhakeme usulünde sanığın usulün uygulanmasını kabul etmesi gerekir. Bunun dışında suçunu kabul ya da ikrar etmesi gibi bir koşul öngörülmemiştir. Bu nedenle söz konusu görüşe katılmıyoruz. Bir görüşe göre; seri muhakeme usulünün Almanya ve Amerika örneklerinde olduğu gibi ikrara dayandırılması, şekli olarak dahi olsa bir gerçekliğe ulaşılması amacını ortaya koyacağından daha isabetli olabilecektir. Bkz. BAYTAZ, Abdullah Batuhan, "Seri Muhakeme Usulü”, Ceza Hukuku ve Kriminoloji Dergisi, Yıl: 2020, Cilt: 8, Sayı: 2, s. 6.

10 Alman CMK ile uzlaşma neticesinde kurulan hükümler istinafa tabi tutulmuş ve hatta Alman CMK m. 302 ile hükmün bir uzlaşma neticesinde kurulmuş olması halinde kanun yolu başvurusunda vazgeçilemeyeceği öngörülmüştür. Bkz. ESHELBACH, Andreas Grube, "StPO § 257c Verständigung zwischen Gericht und Verfahrensbeteiligten”, BeckOK StPO mit RiStBV und MiStra (der. J. Graf), C.H. Beck, München, 2020, Rn. 45.

11 Aynı yönde bkz. YAVUZ, 2020, s. 316. Gerekçedeki ifadenin yanıltıcı olduğu, Avrupa'daki sistemlerin seri muhakeme usulüyle pek çok yönden farklılıklar içerdiği yönünde bkz. TAŞKIN, 2020, s. 117. 
olduğu değerlendirmesi yapılmaktadır ${ }^{12}$. Buna göre; kovuşturmaya alternatif bir yöntem olması, uygulanması için iddianame hazırlanmasında olduğu gibi yeterli şüphenin bulunmasının gerekmesi ${ }^{13}$, soruşturma evresinde büyük oranda savcının kontrolünde gerçekleşmesi, suçun oluşması ve yaptırımın belirlenmesine ilişkin değerlendirmenin savcı tarafından yapılarak söz konusu durumun şüpheli tarafından da kabul edilmesi halinde ve ancak bir mahkeme tarafından onaylandıktan sonra uygulanabilir hale gelmesi ve mahkumiyet kararı ile aynı sonuçları doğurması gibi ceza kararnamelerine has temel özelliklerin hepsi seri muhakeme usulünde de bulunmaktadır ${ }^{14}$.

Doktrinde yapılan değerlendirmelerde seri muhakeme usulü, bazı yönlerden ceza pazarlığına benzetilmektedir. Her iki usulde de savcı etkin konumda bulunmakta ve esasen yargının iş yükünün azaltılması hedeflenmektedir. ABD'de uygulama alanı bulan sanık-savcı pazarlığı yöntemlerinin amacı da yargılamayı hızlandırmaktır. Seri yargılamada olduğu gibi ceza pazarlığı sürecinde de mahkeme onayı söz konusudur ${ }^{15}$.

Yapısal olarak ceza kararnamelerine ve mülga Ceza Muhakemeleri Usulü Kanunu'nda (CMUK) bulunan sulh ceza hakiminin ceza kararnamesi isimli usule benzerliği nedeniyle kurumun ceza kararnamesi olarak isimlendirilmesinin daha yerinde olacağ1 yönünde görüşler bulunmaktadır ${ }^{16}$. Seri muhakeme usulü isminin seçiminde; seri muhakeme ve basit yargılama usullerinin soruşturma ve kovuşturma evrelerinde uygulanabilen usuller olmasından hareket eden kanun koyucunun bu fark nedeniyle

12 ECKSTEIN, Ken, "StPO $\S 407$ Zulässigkeit”, Münchener Kommentar zur StPO Band 3 (der. Christoph Knauer, vd.), C. H. Beck, München, 2019, Rn. 3.

13 TEMMING, Dieter, "Verfahren bei Strafbefehlen", BeckOK StPO mit RiStBV und MiStra (der. J. Graf), C.H. Beck, München, 2020, Rn. 10.

14 YAVUZ, 2020, s. 244.

15 ERDEM / ŞENTÜRK, 2020, s. 580 vd.; TAŞKIN, 2020, s. 104 vd.

16 YAVUZ, 2020, s. 310. Kurumun Cumhuriyet savcisının ceza kararnamesi şeklinde de adlandırılabileceği yönünde bkz. DEĞİRMENCİ, 2020, s. 17; YENİSEY, Feridun / NUHOĞLU, Ayşe, Ceza Muhakemesi Hukuku, Seçkin Yayınevi, Ankara, 2020, s. 847. Terminolojide seri muhakeme usulü teriminin kullanılmasının yanlış olduğu; muhakeme ve usul kelimelerinin birlikte kullanılmaması gerektiği, muhakeme deyişi de terk edilerek seri yargılama teriminin kullanılması gerektiği yönünde bkz. YURTCAN, Erdener, Ceza Yargılaması Hukuku, Seçkin Yayınevi, Ankara, 2019, s. 713. Muhakemenin bir yargılama faaliyeti gerektirdiği, seri muhakemede usulünde ise bir yargılama yapılmadığından kavramın yanlış kullanıldığı yönünde bkz. TAŞKIN, 2020, s. 20; BAYTAZ, 2020, s. 4. 
muhakeme ve yargılama terimlerini tercih ettiği görülmektedir ${ }^{17}$. Her ne kadar muhakeme kavramı yargılamayı da içine alan bir terim olarak kullanılsa da henüz soruşturma aşamasında başvurulan bir usul olması nedeniyle seri muhakeme deyişi tercih edilmiştir ${ }^{18}$. Mevcut terminoloji söz konusu iki kurum arasındaki farkı berraklıkla ortaya koyamamaktadır; ancak aynı durumun ceza kararnamesi teriminin seçilmesi halinde de yaşanabileceğini düşünüyoruz. Zira sulh ceza hakiminin kararnamesi yalnız seri muhakeme usulü ile değil basit yargılama usulü ile de benzer özellikler göstermektedir ${ }^{19}$.

\section{B. Seri Muhakeme Usulünün Hukuki Niteliği}

Seri muhakeme usulü; savcı ile şüphelinin kanunda belirtilen usulle anlaşmaları esasına dayanan, özel bir muhakeme türüdür. Bu usule tabi uyuşmazlıklarda söz konusu usulün denenmiş olması, ceza muhakemesi bağlamında olumlu bir muhakeme şartı oluşturmaktadır ${ }^{20}$. Dolayısıyla seri muhakeme usulünü, belirli uyuşmazlıklarda uygulama

17 Benzer değerlendirme için bkz. KIZILARSLAN, 2019, s. 1907; YENISEY / NUHOĞLU, 2020, s. 853.

18 Bir görüşe göre; muhakeme kavramına ilişkin terminolojik olarak eleştirilebilir yönleri bulunsa da "muhakeme işlemlerinin olağan muhakeme usulüne göre daha çabuk yapıldı̆̆ı ve sonlandirlldlğı" bir muhakeme türünü ifade etmesi bakımından "seri” ifadesinin kullanımı yerindedir. Bkz. YILMAZ / APIŞ, 2020, s. 72 vd. Muhakeme ve yargılama terimlerinin eş anlamlı olduğu; aradaki tek farkın birinin Arapça diğerinin Türkçe olması olduğu yönünde bkz. SELÇUK, Sami, "Doğru terim "MUHAKEME" değil, "YARGILAMA"dır", Marmara Üniversitesi Hukuk Araştırmaları Dergisi, Yıl: 2013, Cilt: 19, Say1: 2, 2013, s. 313.

19 YILMAZ / APİş, 2020, s. 64; Seri muhakeme ve basit yargılama usullerinin mülga CMUK m. 386 vd.'da düzenlenen sulh ceza hakiminin ceza kararnamesi hükümlerinin yeni bir ad altında ve daha dejenere bir biçimde Kanun'a getirilmesi niteliğinde olduğu yönünde bkz. OKTAR, Salih, Seri Muhakeme ve Basit Yargılama Usulleri, 10 Aralık İnsan Hakları Günü Etkinlikleri Kapsamında Yargı Reformu Stratejisinin Değerlendirilmesi, Türkiye Barolar Birliği İnsan Hakları Merkezi Sempozyumunda Yapılan Sunum. https://www.youtube.com/watch?v=65eTxyXAaZY (erişim tarihi 20.08.2020) 15. dk. Sulh ceza hakiminin ceza kararnamesi usulünün seri muhakeme ve basit yargilama olarak CMK'ya ithal edildiği yönünde bkz. KIZILARSLAN, 2019, s. 1909. "Seri muhakeme usulü adl altında getirilen bu düzenlemeler mülga CMUK'da bulunan sulh ceza hakiminin "ceza kararnamesi" ne benzemektedir." Bkz. GÖKCEN, Ahmet / BALCI, Murat / ALŞAHIN, M. Emin, vd., Ceza Muhakemesi Hukuku, Adalet Yayınevi, Ankara, 2020, s. 92. Yürürlükten kaldırılan sulh hakiminin ceza kararnamesi kurumunun başka bir ad altında tekrar canlandırıldığı yönünde bkz. YENISEY / NUHOĞLU, 2020, s. 841.

20 Seri muhakeme usulünün kabul edilmemiş olmasının dava şartlarından biri olduğu yönünde bkz. GÖKCEN / BALCI / ALŞAHIN vd., 2020, s. 89. 
girişiminde bulunulması zorunlu olan ve bu nedenle aynı zamanda muhakeme şartı oluşturan, özel bir ceza muhakemesi türü olarak nitelendirmek mümkündür ${ }^{21}$.

Seri muhakeme usulünün kapsamını belirleyen temel hüküm olan CMK m.250/1'deki ilk cümle "seri muhakeme usulü uygulanabilir" veya "seri muhakeme usulünün uygulanması Cumhuriyet savcısı tarafından takdir edilir" şeklinde, bu yola başvurmanın savcının takdirinde olduğunu gösteren bir ifade ile bitmemektedir. Bilakis cümle sonunda "seri muhakeme usulü uygulanır" şeklinde, emredici bir ifade kullanılmıştır ${ }^{22}$. Dolayısıyla kanuni koşullar gerçekleştiğinde savcının bu yola başvurması zorunludur (Bkz. Yönetmelik m.8/4). Bu husus Yönetmelik m.5/2'de ise; “kanunun 250 nci maddesinin birinci fikrasında sayılan suçlarda kamu davası açılması için yeterli şüphe oluşturacak delil elde edilmesi üzerine kamu davasının açılmasının ertelenmesine karar verilmediği takdirde, seri muhakeme usulünün uygulanması zorunludur." denilmek suretiyle ayrıca vurgulanmıştır.

$\mathrm{Bu}$ zorunluluğun sonucu olarak madde kapsamındaki suçlara ilişkin davalar bakımından bir muhakeme şartı da ihdas edilmiştir. Nitekim seri muhakeme usulünün denenmiş ve bundan sonuç alınamamış olması, bu kapsamdaki suçlarla ilgili davalar bakımından bir muhakeme şartı oluşturmaktadır. Dolayısıyla koşullar gerçekleşmesine rağmen savcının seri muhakeme usulü yoluna gitmeden iddianame düzenlediğinin anlaşı1ması halinde, mahkeme iddianamenin iadesine karar vermelidir (CMK m.174/1/c; Yönetmelik m.5/10).

21 “....seri muhakeme usulü en öz ifade ile Kanun'da gösterilen bazı katalog suçlar için öngörülmüş mecburi bir muhakeme türüdür.” Bkz. YILMAZ / APIŞ, 2020, s. 72.

22 Söz konusu hükmün uygulamada yeknesaklığı sağlamak ve savcıların keyfiliğini önlemek amacıyla getirildiği yönünde bkz. KIZILARSLAN, 2019, s. 1915. Yazara göre; mevcut düzenleme karşısında savcının seri muhakeme usulünün uygulanmaması yönünde bir takdir kullanması mümkün değildir. Ancak kovuşturma aşamasında şüphelinin daha lehine sonuçlar doğabileceği kanaatinin bulunması halinde savcıya kovuşturma aşamasına geçirme yetkisi verilmesi daha uygun olacaktır. Bkz. KIZILARSLAN, 2019, s. 1918. CMK m. 171/2 uyarınca kamu davasını açmada savcıya takdir yetkisi tanınmışken; seri muhakemeye başvurmanın zorunlu tutulmasının sistemsiz bir düzenleme yapıldığı izlenimi uyandırdığı yönünde bkz. YENISEY / NUHOĞLU, 2020, s. 843. 


\section{Seri Muhakeme Usulünün Uygulanma Koşulları}

\section{Genel Olarak}

Kanuni düzenleme dikkate alındığında, seri muhakeme usulüne başvurulmasının bir takım temel koşulları olduğu görülmektedir. Bunun yanında CMK ve ceza muhakemesine ilişkin hükümlerin yer aldığı diğer kanunlarda bulunan düzenlemelerden de bu koşullara ilişkin bazı sonuçlar çıkartılabilmektedir. $\mathrm{Bu}$ iki husus birlikte değerlendirildiğinde, seri muhakeme usulüne başvurulmasının temel koşulları şu şekilde siralanabilir;

1) Muhakeme konusu fiilin oluşturduğu suçun seri muhakeme usulüne tabi olması,

2) Yeterli şüpheye ulaşılmış olması,

3) Kamu davasının açılmasının ertelenmesi kararı verilmemiş olması,

4) Şüpheliye ulaşılmış olması,

5) İştirak halinde işlenen suçlarda tüm fail ve şeriklerin seri muhakeme usulünün uygulanmasını kabul etmesi,

6) Muhakeme şartının gerçekleşmiş olması,

7) Şüphelide yaş küçüklüğü ve akıl hastalığı ile sağır ve dilsizlik hallerinden birinin bulunmamas1.

Aşağıda bu koşullar ayrı başlıklar halinde incelenecektir.

\section{Muhakeme Konusu Suçun Seri Muhakeme Usulüne Tabi Olması}

Seri muhakeme usulünün uygulanabileceği suçları da kanun koyucu tahdidi olarak, tek tek CMK m.250/1'de belirlemiştir. Buna göre;

"Soruşturma evresi sonunda aşağıdaki suçlarla ilgili olarak kamu davasının açılmasının ertelenmesine karar verilmediği takdirde seri muhakeme usulü uygulanır:

a) Türk Ceza Kanununda yer alan;

1. Hakkı olmayan yere tecavüz (madde 154, ikinci ve üçüncü fikra),

2. Genel güvenliğin kasten tehlikeye sokulması (madde 170), 
3. Trafik güvenliğini tehlikeye sokma (madde 179, ikinci ve üçüncü fikra),

4. Gürültüye neden olma (madde 183),

5. Parada sahtecilik (madde 197, ikinci ve üçüncü fikra),

6. Mühür bozma (madde 203),

7. Resmi belgenin düzenlenmesinde yalan beyan (madde 206),

8. Kumar oynanması için yer ve imkan sağlama (madde 228, birinci fikra),

9. Başkasına ait kimlik veya kimlik bilgilerinin kullanılması (madde 268) suçları.

b) 10/7/1953 tarihli ve 6136 sayıl Ateşli Silahlar ve Blçaklar ile Diğer Aletler Hakkında Kanunun 13 üncü maddesinin birinci, üçüncü ve beşinci fikraları ile 15 inci maddesinin birinci, ikinci ve üçüncü fikralarında belirtilen suçlar.

c) 31/8/1956 tarihli ve 6831 sayll Orman Kanununun 93 üncü maddesinin birinci fikrasında belirtilen suç.

d) 13/12/1968 tarihli ve 1072 sayll Rulet, Tilt, Langırt ve Benzeri Oyun Alet ve Makinaları Hakkında Kanunun 2 nci maddesinde belirtilen suç.

e) 24/4/1969 tarihli ve 1163 sayıl Kooperatifler Kanununun ek 2 nci maddesinin birinci fikrasının (1) numaralı bendinde belirtilen suç."

Söz konusu suçların tahdidi olarak sayıldığı bu hüküm, istisnai nitelikte olması dolayısıyla kıyas yoluyla genişletilemez. Dolayısıyla seri muhakeme usulünün uygulanabileceği suçlar burada sayılanlarla sınırlıdır ${ }^{23}$. Bir görüşe göre seri muhakeme usulüne tabi suçların kapsamının dar tutulması nedeniyle sistemden beklenen verim alınamayacaktır. Buna göre; özellikler aile içi kavgalarda tarafların yargılama aşamasında sıkça barışıyor olmaları nedeniyle aile içindeki basit yaralamaların katalog suçlar arasında sayılmaması bir eksikliktir ${ }^{24}$. 7188 sayılı Kanun'un gerekçesinde, seri muhakeme

23 KEZER, 2019, s. 39; ALDEMIR, Hüsnü, Ceza Yargılamasında Seri Muhakeme ve Basit Yargılama Usulleri, Adalet Yayınevi, Ankara, 2019, s. 55; ERDEM / ŞENTÜRK, 2020, s. 587; YURTCAN, 2019, s. 714 .

24 KEZER, 2019, s. 125. 
usulüne tabi suçların ispatı kolay ve ağır nitelikte olmayan suçlar olduğu belirtilmiş;; ancak neden sadece söz konusu suçların bu kapsama alındığı konusunda açıklamaya yer verilmemiştir. Bu suçların ispatının her zaman kolay ve net olduğunu söylemenin ne kadar doğru olduğu bir tarafa bırakılırsa ${ }^{25}$, söz konusu suçların tamamının ağır nitelikte olmadığını söylemek zordur. Örneğin; seri muhakeme usulü kapsamında yer alan parada sahtecilik (TCK m.197), iki yıldan on iki yıla kadar hapis ve on bin güne kadar adlî para cezasını gerektirmektedir. Bunun yanında TCK m.268'de düzenlenen başkasına ait kimlik bilgilerinin kullanılması suçunun cezası bakımından TCK m.267'de düzenlenen iftira suçuna ilişkin hükümlere atıf yapılmıştır. TCK m.267'de düzenlenen iftira suçu bakımından ise TCK m.61/1'in uygulanması kapsamında doğrudan alt ve üst sınırı dikkate alınacaktır. Ancak TCK m.267 suçun temel şeklinden bağımsız yüksek ceza içeren birçok netice sebebiyle ağırlaşmış hal barındırmaktadır. Örneğin, hakkında soruşturma ve kovuşturma yapılmasını engellemek ve suçu kimlik bilgilerini kullandığ mağdurun üzerine atmak için bu kişiye ait kimlik bilgilerini kullanan kimsenin fiili sonucunda, mağdur müebbet veya ağırlaştırılmış müebbet hapis cezasına mahkum olursa, fail 20 yıldan 30 yıla kadar hapis cezası verilecektir (Bkz. TCK m. 268 göndermesiyle TCK m.267/5). Adli Teşkilat Kanunu m.12 gereğince ağır ceza mahkemesinin görev alanına giren bu suçun hafif nitelikte olduğunu söylemek gerçekten çok zordur. Nitekim seri muhakeme usulü kapsamına alınan suçlarla ilgili doktrinde de benzer yönde eleştiriler dile getirilmiştir ${ }^{26}$. Şüpheli bakımından ceza indirimine ilişkin önemli bir

25 “Kataloğa bakıldığında, seçilen suç tiplerinin sübut değerlendirmesinin, daha ziyade detaylı bir araştırmaya gerek kalmaksızın, bir tutanakla ya da hızlı bir bilirkişi incelemesiyle tamamlanmasının mümkün olduğu suçlar olduğu görülmektedir." Bkz. YAVUZ, 2020, s. 252. "Seri muhakemeye tabi suçların objektif bir kritere göre seçilip seçilmediğinde tereddüt oluşmuştur. Hakkı olmayan yere tecavüz dışında genellikle belli bir mağdura karşı değil, kamuya karşı işlenen suçlar olduğu görülmektedir. Soruşturması bakımından ă̆ırlıkl olarak kolluk tutanaklarının büyük belirleyicilik taşıdı̆̆ suç tipleridir. Ancak tamamen pratik kaygıların, özellikle mahkemelerin iş yükünün azaltılması düşüncelerinin etkili olduğu anlaşılmakta, ileride yeni değişikliklerle bu suçların artırılma olasılığı bulunmaktadır.” Bkz. YENISEY / NUHOĞLU, 2020, s. 848.

26 CENTEL, Nur / ZAFER, Hamide, Ceza Muhakemesi Hukuku, Beta Yayınevi, İstanbul, 2020, s. 621; UĞURLUBAY, Gülsün A. Aygörmez / HAYDAR, Nuran / KORKMAZ, Mehmet, "Seri Muhakeme Usulüne İlişkin Sorunlar”, Ankara Sosyal Bilimler Üniversitesi Hukuk Fakültesi Dergisi, Y1l: 2019, Cilt: 1, Sayı: 2, s. 264 vd.; TAŞKIN, 2020, s. 77. Basit yargılama usulünde olduğu gibi suç için öngörülen cezanın üst sınırı dikkate alınarak iki yıllık bir ölçüt kullanılmasının daha yerinde olacağı yönünde bkz. YENISEY / NUHOĞLU, 2020, 846. 
avantaj sağlamakla birlikte, rızasıyla da olsa adil yargılanma hakkından ciddi anlamda feragat etmesi sonucunu doğuran seri muhakeme usulünün ancak gerçekten hafif nitelikteki suçlarla ilgili uygulanması kabul edilmelidir.

\section{Yeterli Şüpheye Ulaşılmış Olması}

CMK m. 250/1'de bu koşul; "Soruşturma evresi sonunda aşağıdaki suçlarla ilgili olarak kamu davasının açılmasının ertelenmesine karar verilmediği takdirde seri muhakeme usulü uygulanır..." ifadesiyle getirilmiştir. Soruşturma evresinin sonu deyişinden anlaşılması gereken ise soruşturmanın eksiksiz bir şekilde tamamlanması ve karar aşamasına gelinmesidir ${ }^{27}$.

CMK m.170/2'de açıkça ifade edildiği üzere, savcılığın soruşturma konusu bir suça ilişkin iddianame düzenleyebilmesi için suçun işlendiğine dair "yeterli şüphe" ye ulaşmış olması gerekir. Bu bağlamda seri muhakeme usulüne gidilebilmesi için gerekli ilk koşul, muhakeme konusu fiilin oluşturduğu suçun şüpheli tarafindan işlendiğine ilişkin yeterli şüphenin bulunmasıdır ${ }^{28}$. Aksi takdirde, yani suçun şüpheli tarafından işlendiğine ilişkin yeterli şüphe bulunmuyorsa; savcı takipsizlik kararı vererek soruşturmayı sonlandırmalıdır (CMK m.172). Bu husus Yönetmelik m.5/2'de; “kanunun 250 nci maddesinin birinci fikrasında sayılan suçlarda kamu davası açılması için yeterli şüphe olușturacak delil elde edilmesi üzerine kamu davasının açılmasının ertelenmesine karar

27 BAYTAZ, 2020, s. 13, YAVUZ, 2020, s. 249; YILMAZ / APİŞ, 2020, s. 74. “...delillerin olayın hemen sonrasında bulunması ve korunması daha kolaydır. Olayın üzerinden bir süre geçtikten sonra, yeniden delil araştırması yapmaya başlamak önceden elde edilebilecek delillerin bulunamamasina yol açabilecektir. Savcının, soruşturmanın hemen başında seri muhakeme usulünü başlatmasının kabul edilmesi halinde, hakimin veya şüphelinin seri muhakeme usulünün uygulanmasinı kabul etmedikleri durumlarda, olayın üzerinden süre geçmiş olduğundan, delillerin toplanamaması veya kaybolması tehlikesi oluşacaktır. Bu nedenle, kanun koyucunun, "soruşturmanın tamamlanmasi sonrasinda seri muhakeme usulünün uygulanmasını kabul etmiş olması muhakeme mantığına daha uygun bir düzenleme olmuştur.” Bkz. KIZILARSLAN, 2019, s. 1916.

28 Aynı yönde bkz. ALDEMIR, 2019, s. 223; ERDEM / ŞENTÜRK, 2020, s. 586; ŞAHİN / GÖKTÜRK, 2020, s. 204; CENTEL / ZAFER, 2020, s. 612. Doktrinde yapılan bir değerlendirmeye göre; seri muhakeme usulü hazırlık aşamasında savcılığın topladığı delillere göre şüphelinin mahkum olacağına yüzde yüz emin olduğu hallerde uygulanabilen bir muhakeme usulüdür. Belirtmek gerekir ki seri muhakeme usulünün uygulanması için böyle bir koşul öngörülmüş değildir. Kovuşturma evresinin sonunda yeterli şüpheye ulaşılmış olması iddianamenin hazırlanması için gerekli ve yeterlidir. Elbette mevcut delil durumuna göre yeterli şüphe derecesinin aşılmış olması da mümkündür; ancak bu bir gereklilik olarak öngörülmemiştir. Bkz. KEZER, 2019, s. 38. 
verilmediği takdirde, seri muhakeme usulünün uygulanması zorunludur.” denilmek suretiyle de vurgulanmıştır (Ayrıca bkz. Yönetmelik m.8/4).

Yeterli şüphe, şüphelinin suçu işlemiş olma ihtimalinin işlememiş olma ihtimalinden daha yüksek olduğu bir şüphe derecesini ifade etmektedir. Dolayısıyla eldeki delil durumuna göre, savcı dava açtığında sanığın mahkum olma ihtimalini beraat etme ihtimalinden yüksek görüyorsa, bu durumda yeterli şüpheye ulaşmış demektir. Bu bağlamda seri muhakeme usulüne tabi bir suçla ilgili olarak bu yola gidilebilmesinin alternatifi, kamu davasının açılacak olmasıdır. Eğer eldeki delil durumu vb. sebeplerle, kamu davası açma imkanı bulunmuyorsa, seri muhakeme usulüne gidilmeksizin takipsizlik kararı ile muhakeme sona erdirilmelidir (Yönetmelik m.8/3). Seri muhakeme usulü soruşturma aşamasında başvurulan bir usuldür. $\mathrm{Bu}$ bağlamda iddianamenin iadesinden sonra da seri muhakeme usulüne başvurulması mümkündür ${ }^{29}$.

$\mathrm{Bu}$ noktada ayrıca belirtmek gerekir ki; Cumhuriyet savcısı suçun seri muhakemelik olduğunu anladığında, maddi gerçeği araştırmaktan imtina etmemelidir. Nitekim bu usulü uygulamak bakımından, şüphelinin suçu işlediğine dair en azından yeterli şüphe seviyesine ulaşmış olmalıdır ${ }^{30}$. Eğer şüphelinin suç üstlenmesi (TCK m.270)

29 ALDEMIR, 2019, s. 223.

$30 \mathrm{Bu}$ bağlamda seri muhakeme usulünün uygulandığı hallerde de suç haberinin alınmasından iddianamenin hazırlanabilmesi için gereken koşulların oluştuğu evreye kadar soruşturma işlemleri genel ceza muhakemesi usulünce yapılmaktadır. Bkz. YILMAZ / APIŞ, 2020, s. 74. Soruşturmanın tamamlanmış olması ve uyuşmazlıkla ilgili delillerin tespit edilmesi, seri muhakeme usulünün şüpheli tarafından kabul edilmesini kolaylaştıracaktır. Bkz. KIZILARSLAN, 2019, s. 1917. "Öncelikle burada isnat edilen suçla ilgili tüm delillerin toplanması gerekmektedir. Tüm deliller toplandıktan sonra şüpheli hakkında kamu davası açılması gerekip gerekmediği hususu tartışmaya açılmalı ve bu durum cumhuriyet savcısı tarafindan değerlendirilmelidir. Şüphelinin atılı suçu işlediği yönünde bir kanaat oluşmasl ve yeterli delil elde edilmesi durumunda suçun seri muhakeme usulüne tabi olup olmadı̆̆ belirlenmelidir." Bkz. ÇALIŞKAN, Suat, Ceza Muhakemesinde Seri Muhakeme Usulü, https://www.hukukihaber.net/ceza-muhakemesinde-seri-muhakeme-usulu-makale,7314.html (erişim tarihi 27.08.2020), p. 75. "CMK m. 250/8-c kapsamında isnat olunan suçun hangi kanun maddesinden ibaret olduğunu belirtmekle yetinilmemeli, tam tersine anılan hususlart içeren gerekçeli bir iddiada bulunulmalıdır. Bu sadece isnadı ögrenme hakkının bir gereği değil, aynı zamanda etkin bir savunmada bulunmanın da ana koşuludur. Bu noktada Yargıtayın iddianameler için öngördüğü standartların, talepnameler için de en azından isnat olunan suç ile alakall yerine getirilmesi gerekir." Bkz. UĞURLUBAY / HAYDAR / KORKMAZ, 2019, s. 262. “...seri muhakeme usulü, soruşturmanın başından itibaren Cumhuriyet savcısının gözetim ve denetiminde kolluk görevlileri aracılığıla delil toplanması işlemlerinin yapılması durumunu ortadan kaldırmaz. Bu usulün herhangi bir nedenle uygulanamaması halinde soruşturmaya geri dönüleceğinden, soruşturma evresinin genel muhakeme sürecinde olduğu gibi yürütülmesi ve delillerin toplanması gerekir.” Bkz. CENTEL / ZAFER, 2020, s. 612. 
gibi bir durum olduğunu tespit ederse, soruşturma konusu fiille ilgili olarak şüpheli hakkında yeterli şüphe olmaması nedeniyle takipsizlik kararı vermeli (CMK m.172); buna karşın suç üstlenmeden dolayı da hakkında soruşturma başlatmalıdır. Suçun seri muhakemelik olmasının savcının araştırma yükümlülüğünü ortadan kaldırmadığı Yönetmelik m.8/1'de açıkça vurgulanmıştır. Buna göre; “Cumhuriyet savcısı seri muhakeme usulüne tâbi bir suçun işlendiği izlenimini veren bir hâli öğrenir öğrenmez kamu davasını açmaya yer olup olmadığına karar vermek üzere hemen işin gerçeğini araştırmaya başlar. Soruşturma konusu suçun seri muhakeme usulüne tâbi olması Cumhuriyet savcısının maddi gerçeği araştırma yükümlülüğünü ortadan kaldırmaz.",

\section{Kamu Davasının Açılmasının Ertelenmesi Kararı Verilmemiş Olması}

Kamu davasının açılmasının ertelenmesi kararı verilecek haller ve koşulları CMK m.171/2 vd. gösterilmiştir. CMK m.250/1'de ise kanun koyucu; "soruşturma evresi sonunda aşağıdaki suçlarla ilgili olarak kamu davasının açılmasının ertelenmesine karar verilmediği takdirde seri muhakeme usulü uygulanır" demek suretiyle, kamu davasının açılmasının ertelenmesi kararının verildiği hallerde, suç seri muhakeme usulüne tabi olsa bile bu usulün uygulanamayacağını açıkça belirtmiştir. Bu bağlamda kamu davasının açılmasının ertelenmesi kararı verildikten sonra, şüpheli beş yıllık denetim süresi içerisinde yeniden kasıtlı bir suç işlerse, hakkında kamu davası açılacak, suç seri muhakeme usulüne tabi olsa bile, denetim süresinin ihlalinden sonra bu usul uygulanamayacaktır.

Tekrar belirtmek gerekir ki, kamu davasının ertelenmesine karar verilmediği takdirde savcılık seri muhakeme usulünü uygulamak zorundadır. Bu konuda bir takdir yetkisi bulunmamaktadir ${ }^{31}$.

\section{5. Şüpheliye Ulaşılmış OIması}

Seri muhakeme usulüne başvurulabilmesi için gerekli bir diğer önemli koşul ise şüpheliye ulaşılmış olmasıdır. Aksi takdirde seri muhakeme usulünün gerçekleştirilmesi

31 Bu bağlamda örneğin, seri muhakemelik bir suç işlemiş kimse daha önce kasıtlı bir suçtan mahkum olmuş ise hakkında kamu davasının açılmasının ertelenmesi kararı verilemeyecektir. Ancak Cumhuriyet savcısı, Kanun'un emredici hükmü gereğince bu kimse bakımından seri muhakeme usulünü uygulayacaktır. Bkz. UĞURLUBAY / HAYDAR / KORKMAZ, 2019, s. 264. 
mümkün olmayacaktır. Kanun koyucu buna ilişkin hükme CMK m.250/13'te yer vermiştir (Ayrıca bkz. Yönetmelik m.5/6). Buna göre; "Resmî mercilere beyan edilmiş olup da soruşturma dosyasında yer alan adreste bulunmama veya yurt dışında olma ya da başka bir nedenle şüpheliye ulaşılamaması hâlinde, seri muhakeme usulü uygulanmaz."

\section{6. İştirak Halinde İşlenen Suçlarda Tüm Fail ve Şeriklerin Seri Muhakeme Usulünün Uygulanmasını Kabul Etmesi}

Kanun koyucu iştirak halinde işlenen suçlarda, tüm fail ve şeriklerin seri muhakeme usulünün uygulanması kabul etmesi durumunda bu usulün uygulanabileceğini kabul etmiştir. Buna göre "suçun iştirak hâlinde işlenmesi durumunda şüphelilerden birinin bu usulün uygulanmasını kabul etmemesi hâlinde seri muhakeme usulü uygulanmaz (CMK m.250/11)." İştirak edenlerin yardım eden, azmettiren ya da fail olmasının önemi yoktur $^{32}$. Hangi tür iştirak içinde olurlarsa olsunlar ya bu kişilerin tamamı seri muhakeme usulünü kabul edecek ve bu usul uygulanacaktır ya da içlerinden bir tanesi bile söz konusu usulün uygulanmasını kabul etmezse, seri muhakeme usulü hiçbiri bakımından uygulanamayacaktır ${ }^{33}$.

\section{Muhakeme Şartının Gerçekleşmiş Olması}

Seri muhakeme usulünün uygulama alanı bulabilmesi bakımından gerekli bir diğer koşul da muhakeme engeli bulunmamasıdır. Bu bağlamda uyuşmazlık konusu fiilin oluşturduğu suça ilişkin bir muhakeme şartı varsa; ancak bu şart gerçekleştiğinde seri muhakeme usulü uygulanabilecektir. Örneğin; yasama dokunulmazlığından faydalanan bir milletvekilinin seri muhakeme usulüne tabi suçlardan birisini işlediği tespit edildiğinde, muhakeme usulünün uygulanarak milletvekili hakkında hüküm kurulması

32 ERDEM / ŞENTÜRK, 2020, s. 588; KIZILARSLAN, 2019, s. 1924; YAVUZ, 2020, s. 255.

33 DEĞİRMENCI, 2020, s. 19. "Şeriklerden biri muhakeme usulünü kabul etmezse hiçbir şüpheli hakkinda seri yargılanma usulü uygulanmaz. Savcllk makamı işbu durumun önüne geçmek için dosyalar tefrik ya da birleştirme yoluna gidilemez.” Bkz. KEZER, 2019, s. 61. 
mümkün değildir. Çünkü “dokunulmazlığın bulunmaması” na ilişkin muhakeme şartı gerçekleşmemiştir ${ }^{34}$.

Basit yargılama usulünün düzenlediği CMK m. 251/7' de soruşturma veya kovuşturma yapılması izne ya da talebe bağlı olan suçlar hakkında basit yargılama usulünün uygulanmayacağı hükme bağlanmışken seri muhakeme usulü bakımından böyle bir hüküm sevk edilmemiştir. Katalog suçlar arasında bu nitelikte bir suç bulunmadığından söz konusu düzenlemenin bir fark yaratmayacağı söylenebilirse de ileride yapılacak kanuni bir değişiklikle katalog suçların kapsamının genişletilmesi halinde ayrıca değerlendirme yapmak gerekir. ${ }^{35}$

\section{8. Şüphelide Yaş Küçüklüğü ve Akıl Hastalığı ile Sağır ve Dilsizlik Hallerinden Birinin Bulunmaması}

Şüpheli bakımından yaş küçüklüğü ve akıl hastalığı ile sağır ve dilsizlik hâllerinin bulunmaması seri muhakeme usulünün uygulanması için gerekli koşullardandır. Kanun koyucu buna ilişkin açık bir hükme kanunda yer vermiştir. Buna göre; "seri muhakeme usulü, yaş küçüklüğ̈̈ ve akıl hastalı̆̆l ile sağır ve dilsizlik hâllerinde uygulanmaz (CMK m.250/12)." Şüpheli seri muhakeme usulünü kabul ederek adil yargılanma hakk1 bakımından kendisine tanınmış olan önemli birtakım güvencelerden vazgeçmektedir (delillerin mahkeme tarafından değerlendirilmesi, hükmün kanun yolunda ayrıntılı denetimi, vb). $\mathrm{Bu}$ nedenle şüpheli, seri muhakeme kurumuna ilişkin tam olarak aydınlatılmış olmalı ve rızası bu şekilde alınmalıdır. Eğer şüphelinin tam aydınlatılmış bir rızası bulunmuyorsa, seri muhakeme usulünün uygulanması söz konusu olamayacaktır. Bu bağlamda kanun koyucu; "aydınlatılmış rıza” nın bu gruptakiler bakımından söz konusu olamayacağını kabul ederek, bu kimselerin şüpheli olduğu uyuşmazlıklarda seri muhakeme usulünün uygulanma ihtimalini ortadan kaldırmıştır ${ }^{36}$.

\footnotetext{
34 “...soruşturma yapılmasını engelleyen muhakeme engeli olması halinde C. Savcısının öncelikle bu engelin ortadan kalkması için gerekli usuli işlemleri gerçekleştirmesi, engelin ortadan kalkmayacă̆ anlaşıldı ̆̆ takdirde kovuşturmaya yer olmadı̆̆ına dair kararın verilmesi gerekmektedir." Bkz. BAYTAZ, 2020, s. 14.

35 Soruşturma ve kovuşturması izne ya da talebe bağlı olan suçların, seri muhakeme usulünün uygulanamayacağı istisnai bir grup suç olduğu yönünde bkz. DEĞİRMENCİ, 2020, s. 19.

36 Aynı yönde bkz. KIZILARSLAN, 2019, s. 1923 vd.
} 
Böyle bir kanuni düzenleme yapılmasının bir diğer sebebi de şüpheli bakımından sayılan durumlardan birinin bulunup bulunmadığının çoğu kez bilirkişi incelemesi ile tespit edilmesinin gerekmesidir ${ }^{37}$.

\section{Seri Muhakeme Usulünün Uygulanması}

\section{Genel Olarak}

Seri muhakeme usulünün ne şekilde uygulanacağı CMK m.250 ve ilgili yönetmelikte hükme bağlanmıştır. $\mathrm{Bu}$ düzenlemeler 1şığında söz konusu usulün uygulanması farklı safhalara ayrılarak irdelenebilir. Bununla birlikte şu hususu da başlangıçta belirtmek gerekir ki; bu usulün uygulama sürecinin kanun yolu aşaması hariç bir-iki gün içinde bitirilmesi esastır. Aşağıda her bir safha ayrı ayrı incelendiğinden, ilk bakışta bu usulün uygulanmasının belki aylarca süreceği düşünülebilir. Ancak belirttiğimiz üzere kanun yolu aşaması hariç bilgilendirmeden hükmün kurulmasına kadar ki süreç bir-iki gün içinde çoğu kez bitirilmiş olacaktır. Elbette ki istisnai durumlar ortaya çıkabilecektir. Örneğin; teklif yapıldıktan sonra şüphelinin bir aya kadar düşünme süresi istemesi hallerinde, sürecin tamamlanması oldukça uzun sürebilecektir. Ama esasta öngörülen ve istenen husus, seri muhakeme usulünün, adı üzerinde, çok seri ve hızlı tamamlanmasıdır. $\mathrm{Bu}$ düşünceyi yansıtan hükümlere de yönetmelikte yer verilmiştir. Örneğin Yönetmelik m.10/9'da “şüphelinin teklifi müdafi huzurunda kabul etmesi halinde şüpheli, aynı gün mahkemeye yönlendirilir” denilerek, muhakemenin seri şekilde ilerletilmesi gerekliliği vurgulanmıştır. Bu usulde muhakeme seri şekilde ilerletilecek olsa da bu süreci safhalara ayırarak incelemek, kurumu daha sistematik olarak ele almak bakımından kolaylık sağlamaktadır. Bu nedenle, uygulamada birçok kez iç içe geçecek olan sürecin safhalarını burada ayrı başlıklar halinde incelemeyi uygun buluyoruz.

Yönetmelik hükmü dikkate alındığında, seri muhakeme usulü uygulanırken yaptırımın belirlenmesi safhasının, teklif safhasından önce geldiği görülmektedir ${ }^{38}$. Biz

37 ERDEM / ŞENTÜRK, 2020, s. 589.

38 Bkz. aynı yönde; YILMAZ / APIŞ, 2020, s. 77; KIZILARSLAN, 2019, s. 1929, 1931. Aksi görüşe göre ise şüphelinin usulün uygulanmasını kabul etmesi halinde seri muhakeme usulünün uygulanması kararı verilecek ve cezanın belirlenmesi safhasına geçilecektir. Bkz. ALDEMİR, 2019, s. 63; ERDEM / ŞENTÜRK, 2020, s. 590. 
de incelememizi bu şekilde gerçekleştireceğiz. Bu bağlamda seri muhakeme usulünün uygulanma safhaları sırasıyla şu şekildedir; 1) Bilgilendirme Safhası 2) Yaptırımın Belirlenmesi Safhast 3) Teklif Safhası 4) Talep Safhası 5) İnceleme Safhası 6) Hükmün Kurulması Safhası 7) Kanun yolu Safhası. Aşağıda her bir safha sırasıyla ele alınıp incelenecektir.

\section{Bilgilendirme Safhası}

Cumhuriyet savcısı uyuşmazlık konusu suçun seri muhakeme usulüne tabi olduğunu ve bu usulü uygulamak için gerekli diğer koşulların bulunduğunu tespit ederse, kendisi doğrudan veya kolluk görevlileri aracılığıyla, şüpheliyi, seri muhakeme usulü hakkında bilgilendirir (CMK m.250/2; Yönetmelik m.8/2). Kanun koyucu, şüphelinin teklifi tam olarak aydınlatılmış şekilde kabul etmesini aradığından, bilgilendirmenin net şekilde yapılması büyük önem arz etmektedir. Nitekim neyle karşılaşacağını bilmeyen birinin, kendisine teklif edilen uygulamayı kabul etmeme eğiliminde olması muhtemeldir. $\mathrm{Bu}$ bağlamda bilgilendirmenin tam ve net olarak yapılması gerekir. Aksi takdirde mahkemelerin iş yükünü azaltacağı inancıyla getirilen bu kurumun kendisinden beklenen oranda uygulama alanı bulması zor olacaktır. Bununla birlikte adil yargılamaya ilişkin birçok güvenceden vazgeçen şüphelinin, bu rızasının tam aydınlatılmış olarak alınmış olması, söz konusu usulün uygulamasının makul karşılanabilmesi bakımından da “olmazsa olmaz" bir gerekliliktir" ${ }^{39}$. Bu husus, Yönetmelik m.5/3'te “seri muhakeme usulü, şüphelinin müdafi huzurunda özgür iradesi ile bu usulün uygulanmasını kabul etmesi hâlinde gerçekleştirilir." denilerek vurgulanmıştır.

\section{Yaptırımın Belirlenmesi Safhası}

CMK m. 250/3 vd. fikralara bakıldığında, sanki bilgilendirme aşamasını teklif aşaması takip edecekmiş gibi bir anlam çıkmaktadır. Doktrinde bir görüşe göre; Cumhuriyet savcısı önce teklifte bulunacak, teklifin şüpheli tarafından kabul edilmesi halinde somut cezanın belirlenmesi aşamasına geçilecektir ${ }^{40}$. Oysa bu durum yukarıda ayrıntılı olarak açıkladığımız üzere, seri muhakeme usulünün yapısına uygun değildir. Bu

39 Bkz. aynı yönde; KEZER, 2019, s. 41 vd.; YILMAZ / APIŞ̧, 2020, s. 76; UĞURLUBAY / HAYDAR / KORKMAZ, 2019, s. 266-267.

40 ERDEM / ŞENTÜRK, 2020, s. 590; YURTCAN, 2019, s. 715 vd. 
nedenle de kurumun yaygın olarak uygulama alanı bulmasına engel teşkil edebilecektir. Ancak daha sonra çıkartılan Yönetmelik m.10/2'de "seri muhakeme usulünün uygulanması Cumhuriyet savcısı tarafindan şüpheliye teklif edilir; şüpheliye uygulanacak yaptırımların neler olduğu açıklanır" denilmek suretiyle teklif sırasında uygulanacak yaptırımların da şüpheliye aktarılacağı ifade edilmiştir. Buradan çıkan anlam, teklif aşamasına geçilmeden önce savcının uygulanacak yaptırımları belirlemiş olması gerektiği yönündedir. Aşağıda şüpheli hakkında uygulanacak yaptırım belirlenirken hangi esaslar doğrultusunda hareket edileceği ayrı başlıklar halinde açıklanacaktır.

Bir görüşe göre, yaptırıma ilişkin hususların Cumhuriyet savcısı tarafından, onun takdiri ile belirleniyor olması seri muhakeme usulünün kanun koyucu tarafından bir pazarlık yöntemi olarak kabul edilmediğini ortaya koymaktadır. Zira yaptırımın belirlenmesi aşamasında şüpheli ile Cumhuriyet savcısı arasında bir müzakere yapılmamaktadır ${ }^{41}$. Ancak görüş sahipleri, yaptırıma karar verme konusunda çok geniş bir takdir hakkına sahip bulunan Cumhuriyet savcısı ile hukuken bir açıklık olmasa da örtülü bir müzakere olacağını kabul etmektedir ${ }^{42}$.

CMK m.250/4'ün açık düzenlemesine göre, şüpheli hakkında mahkemeden talep edilecek somut ceza belirlenirken sadece TCK m.61'in birinci fikrası gereğince belirlenen ceza yarı oranında indirilecektir. ${ }^{43}$ Bunun dışında cezanın belirlenmesinde TCK m.61'in

41 YAVUZ, 2020, s. 266.

42 YAVUZ, 2020, s. 285.

43 Temel cezanın belirlenmesine ilişkin TCK m.61/1 hükmü ise şu şekildedir; Cezanin belirlenmesi

Madde 61. - (1) Hakim, somut olayda;

a) Suçun işleniş biçimini,

b) Suçun işlenmesinde kullanılan araçları,

c) Suçun işlendiği zaman ve yeri,

d) Suçun konusunun önem ve dĕgerini,

e) Meydana gelen zarar veya tehlikenin ă̆ırlı̆̆ını,

f) Failin kast veya taksire dayalı kusurunun ă̆ırlı̆̆ını,

g) Failin güttüğü amaç ve saiki göz önünde bulundurarak, işlenen suçun kanuni tanımında öngörülen cezanın alt ve üst sinırı arasında temel cezayı belirler. 
diğer fikraları dikkate alınmayacaktır. Söz konusu düzenleme şu şekildedir; "Cumhuriyet savcısl, Türk Ceza Kanununun 61 inci maddesinin birinci fikrasında belirtilen hususlarl göz önünde bulundurarak, suçun kanuni tanımında öngörülen cezanın alt ve üst sınırı arasında tespit edeceği temel cezadan yarl oranında indirim uygulamak suretiyle yaptırımı belirler (CMK m.250/4; Ayrıca bkz. Yönetmelik m.10/5).”

Bu bağlamda talep edilecek ceza belirlenirken, örneğin işlenen suçta ağırlaştırıcı ya da hafifletici sebepler varsa bunlar cezanın belirlenmesinde etkili olmayacaktır. Bir başka ifadeyle suçun temel şekline bağlı olarak cezayı arttıran bir nitelikli hal varsa (örneğin yaralama eşe karşı işlenmişse-TCK m.86/3) bu dikkate alınmaksızın temel ceza belirlenecektir. Yine suçun olası kastla işlenmesi söz konusuysa, ceza hesaplanırken olası kast indirimi dikkate alınmayacak ya da bilinç taksir hali söz konusuysa bundan kaynaklı artırım yapılmayacaktır. Nitekim CMK m.250/4'te doğrudan TCK m.61/1'e atıf yapılarak, cezanın sadece bu fikra hükümlerine göre belirleneceği ifade edilmiştir. Olası kasta göre cezanın indirilmesi veya bilinçli taksir dolaysıyla attırılması ise TCK m.61/2'de, ağırlaştırıcı veya hafifletici neden olan nitelikli hallerin göz önünde bulundurulmasına ilişkin düzenleme ise TCK m.61/4'te hükme bağlanmıştır. Bunun yanı sıra teşebbüs halinde kalmış suçlarda indirim yapılması ya da yaş indirimi gibi hususların ceza belirlenirken uygulanması yahut yardım edenin cezasının faile göre indirilmesi de mümkün değildir. Nitekim bu hususlar TCK m.61/5'te düzenlenmiştir. Oysa yukarıda da ifade ettiğimiz üzere, CMK m.251/4'teki açık ifadeye göre yaptırım belirlenirken sadece TCK m.61/1 düzenlemesi dikkate alınacaktır ${ }^{44}$.

Cumhuriyet savcısı sadece burada belirtilen kıstaslar doğrultusunda cezanın alt ve üst sınırı arasında bir miktar belirleyip, bu miktarı yarı oranında indirerek şüpheli için talep edilecek somut cezayı belirleyecektir. İndirim oranı konusunda Cumhuriyet

44 DEĞIRMENCİ, 2020, s. 20; ERDEM / ŞENTÜRK, 2020, s. 590; YAVUZ, 2020, s. 268. Aksi görüşe göre ise TCK'nın 61. maddesinin ilk fikrası dikkate alınarak temel cezanın belirleneceğine dair kanuni düzenleme, 61. maddenin diğer fikralarının- örneğin iştirak bakımından beşinci fikranınuygulanmayacağı anlamına gelmemektedir. Bkz. ŞAHİN / GÖKTÜRK, 2020, s. 205. Savcının cezayı belirlerken 61. maddede öngörülen tüm kriterleri dikkate alması gerektiği yönünde bkz. YURTCAN, 2019, s. 716. 61. Maddenin diğer fikralarının uygulanabilmesi için bir gözden geçirme yapılması gerektiği yönünde bkz. BAYTAZ, 2020, s. 30. 
savcısının bir takdir hakkı bulunmamaktadır. Seri muhakeme usulünün uygulandığı her durumda 61. maddenin ilk fikrasında belirtilen ölçütler uygulanarak ceza miktarı belirlenecek ve bu miktar üzerinden her halde yarı oranında indirim yapılacaktır ${ }^{45}$.

Kanun koyucu TCK m.61/1 çerçevesinde belirlenen cezada yarı oranında indirim yapılması suretiyle talep edilecek somut cezanın, koşulların bulunması halinde TCK m.50'deki seçenek yaptırımlara çevrilmesine ya da TCK m.51'e göre ertelemeye konu olmasına da imkan tanımıştır ${ }^{46}$. Cezanın seçenek yaptırımlara çevrilmesi veya ertelenmesine ilişkin söz konusu düzenleme ise şu şekildedir; "Dördüncü fikra uyarınca sonuç olarak belirlenen hapis cezası Cumhuriyet savcısı tarafından, koşulları bulunması hâlinde Türk Ceza Kanununun 50 nci maddesine göre seçenek yaptırımlara çevrilebilir veya 51 inci maddesine göre ertelenebilir (CMK m.250/5; Ayrıca bkz. Yönetmelik m.10/7)). " Bu bağlamda talep edilmek üzere belirlenen somut ceza, seçenek yaptırımlara çevrilmenin koşullarını sağlıyorsa, Cumhuriyet savcısı belirlediği somut yaptırımı seçenek yaptırımlara çevirerek talepte bulunabilecektir ${ }^{47}$. Benzer şekilde koşullarını sağlıyorsa, Cumhuriyet savcısı talepnamede bu cezanın ertelenmesini de isteyebilecektir. Ancak burada kanun koyucu savcıya takdir yetkisi tanımıştır. Koşullar bulunsa bile savcı, cezanın seçenek yaptırımlara çevrilmesini veya ertelenmesini talep etmeyebilecektir ${ }^{48}$. Bununla birlikte bu durum savcıya bir keyfilik alanı tanımamaktadır. Nitekim savcının koşulları bulunduğu hallerde bu kurumları uygulamamasının makul bir sebebi

45 ALDEMIR, 2019, s. 73 vd.; DEĞİRMENCI, 2020, s. 21; ERDEM / ŞENTÜRK, 2020, s. 591; KIZILARSLAN, 2019, s. 1933.

46 Hapis cezasının kısa süreli olup olmadığı yarı oranında indirim yapıldıktan sonra bulunan ceza miktarına göre belirlenmelidir. Sanığın birden fazla suçtan mahkum olması durumunda ise sürenin belirlenmesinde toplam ceza miktarı değil, her bir suç bakımından ayrı ayrı değerlendirme yapılmalıdır. Bu durumda, şüpheli birden fazla seri muhakemelik suç işlemiş ise; koşullarının bulunması durumunda şüpheli hakkında bunlardan her biri bakımından ayrı ayrı seri muhakeme usulü işletilecek ve bu suçlardan her biri bakımından sonuç ceza kısa süreli ise TCK'nın 50. maddesi uygulanabilecektir. Bkz. TAŞKIN, 2020, s. 50 vd.

47 Doktrinde bu konuda yapılan bir değerlendirmeye göre seri muhakeme usulüne tabi suçlar için öngörülmüş olan cezaların genelde kısa süreli hapis cezaları olması ve Cumhuriyet savcısının 1/2 oranında indirim yapma zorunluluğu karşısında seri muhakeme usulünün uygulandığı neredeyse tüm hallerde cezalar seçenek yaptırımlara çevrilebilecek ve bu tür suçlar fiilen kovuşturma sistemi dişına çıkarılacaktır. Bkz. KIZILARSLAN, 2019, s. 1933-1934.

48 "Cumhuriyet savcısı bu iki seçenekten birisini tercih etme ya da hiçbirisini tercih etmeme konusunda takdir yetkisine sahiptir.” Bkz. YAVUZ, 2020, s. 274. 
bulunmalidir ${ }^{49}$.

Eğer hükmün açıklanmasının geri bırakılmasının CMK m.231/5 vd. yer alan koşulları varsa, Cumhuriyet savcısı mahkemeye vereceği talepnamede, kurulacak mahkumiyet hükmünün açıklanmasının geri bırakılmasını isteyebilecektir. Nitekim CMK m.250/6'da "bu maddeye göre belirlenen yaptırımlar hakkında, Cumhuriyet savcısı tarafindan, koşulları bulunması halinde 231 inci madde klyasen uygulanabilir" denilmektedir (Ayrıca bkz. Yönetmelik m.10/6).

Son olarak belirtmek gerekir ki; seri muhakeme usulünde cezanın kanunda öngörülen usulle belirlenmesi, bu cezanın ertelenmesi, seçenek yaptırımlara çevrilmesi ya da hükmün açıklanmasının geri bırakılmasına karar verilmesi, fail hakkında, işlediği suç nedeniyle uygulanacak güvenlik tedbirlerine karar verilmesini engellemez (Yönetmelik m.5/9). Nitekim CMK m.250/7'ye göre; “bu madde kapsamında yaptırım uygulanması, güvenlik tedbirlerine ilişkin hükümlerin uygulanmasına engel teşkil etmez." Dolayısıyla savcı, talepnamede uygulanması gereken güvenlik tedbirlerini de talep etmelidir ${ }^{50}$. Örneğin işlediği suç nedeniyle şüphelinin TCK m.53 gereğince belirli hakları kullanmaktan yoksun bırakılması gerekiyorsa, talepnamede de bu güvenlik tedbirinin fail hakkında uygulanması istenecektir ${ }^{51}$. Ancak belirtmek gerekir ki, belirli hakları kullanmaktan yoksun bırakma tedbiri mahkumiyetin kendiliğinden bir sonucu ve ona bağlı bir güvenlik tedbiri olduğundan infaz aşamasında re'sen de değerlendirilebilir ${ }^{52}$.

\section{Teklif Safhası}

Seri muhakeme usulünün uygulanması sürecinde, bilgilendirme ve yaptırımın belirlenmesi safhalarını, şüpheliye seri muhakemesi usulünün uygulanmasına ilişkin

49 Önemli bireyselleştirme araçlarından olan bu iki kurumun, cezanın özel önleme amacını gerçekleştirmeye hizmet edecek biçimde kullanılması bakımından Cumhuriyet savcısının şüpheli hakkında sosyal inceleme raporuna göre takdirini kullanması gerektiği yönünde bkz. YAVUZ, 2020, s. 275.

50 Müsadere kararı verilebilmesi için kasten işlenmiş bir suçun varlığı gerektiğinden seri muhakeme usulünde Cumhuriyet savcısının bu konuda karar vermesinin muhakeme sistemimize uygun olmadığı, ayrıca dava açılması gerektiği yönünde bkz. BAYTAZ, 2020, s. 30 vd.

51 DEĞİRMENCİ, 2020, s. 21.

52 ERDEM / ŞENTÜRK, 2020, s. 593. 
teklifte bulunulması safhası takip eder. $\mathrm{Bu}$ bağlamda bilgilendirme ve yaptırımın belirlenmesinden sonra, Cumhuriyet savcısı tarafından seri muhakeme usulünün uygulanması şüpheliye teklif edilir ve şüphelinin müdafii huzurunda teklifi kabul etmesi hâlinde bu usul uygulanır (CMK m.250/3). Belirtmek gerekir ki seri muhakeme usulünü teklif yetkisi yalnızca Cumhuriyet savcisına aittir. Bu safhada, bilgilendirme safhasında olduğu gibi kolluğa bir yetki tanınmamıştır ${ }^{53}$.

Teklif safhasında öncelikle, "Cumhuriyet savcısı şüpheliyi seri muhakeme usulünün uygulanmasını teklif etmek amacıyla en kısa sürede davet eder. Davet; telefon, telgraf, faks, elektronik posta gibi iletişim araçlarından yararlanmak suretiyle de yapılabilir (Yönetmelik m.9/1). Şüphelinin mazeretsiz olarak davete icabet etmemesi, resmî mercilere beyan edilmiş olup da soruşturma dosyasında yer alan adreste bulunmaması veya yurt dışında olması ya da başka bir nedenle şüpheliye ulaşılamaması hâlinde Cumhuriyet savcısı tarafindan bu durum tutanağa bağlanır ve soruşturmaya genel hükümlere göre devam edilir (Yönetmelik m.9/2; Ayrıca ayn yönde bkz. Yönetmelik m.10/4).”

Kanun koyucu, yerinde olarak, seri muhakeme usulünün uygulanmasına ilişkin teklifin, bizzat Cumhuriyet savcısı tarafından yapılmasını hükme bağlamıştır. Teklif yapılırken kişinin yanında müdafiin bulunması bir zorunluluktur. Bu husus aşağıda daha ayrıntılı incelenecektir. Ancak burada bu kısa bilgiyi vermekle yetinmeyi uygun buluyoruz. Cumhuriyet savcisı teklifte bulunurken, ilk bilgilendirme kolluk tarafindan yapılmışsa bile, teklif öncesi bilgilendirmeyi mutlaka kendisi yapmalıdır (Yönetmelik m.10/1). Bu noktada şüphelinin tam olarak aydınlanmış olup olmadığını da test etmelidir $^{54}$. Nitekim süreç onun denetim ve gözetimindedir. Eğer bilgilendirmede bir eksiklik hissederse, teklifi yapmadan önce özel olarak bu eksikliği gidermelidir. Bu aşamada teklif öncesi şüpheliye yapılacak bilgilendirme;

53 ERDEM / ŞENTÜRK, 2020, s. 588; KEZER, 2019, s. 43; YILMAZ / APİŞ, 2020, s. 77.

54 Bir görüşe göre; şüpheliye bilgilendirme yapılırken elde edilen deliller ve muhakemeyi etkileyebilecek görüşler hakkında bilgi verilmemekte; şüpheli, lehine olan delillerin toplanıp toplanmadığını ve mevcut delil durumunu bilmeden teklif hakkında karar vermektedir. Bu ise şüpheliyi dezavantajlı ve savcı karşısında etkisiz bir konuma getirmektedir. Bu nedenlerle seri muhakeme usulünün silahların eşitliği ilkesine aykırı olduğu savunulmaktadır. Bkz. UĞURLUBAY / HAYDAR / KORKMAZ, 2019, s. 280. 
a) İsnat edilen eylem, eylemin oluşturduğu suç ile bu suçun seri muhakeme usulü kapsamına girdiği,

b) Kamu davasının açılması için yeterli şüphenin bulunduğu,

c) Özgür iradesiyle ve müdafi huzurunda kabul ettiği takdirde bu usulün uygulanacă̆l ve belirlenecek temel cezanın yarı oranında indirileceği,

ç) Cumhuriyet savcısı tarafindan teklif edilen yaptırım hakkında talep doğrultusunda mahkemenin hüküm kuracağl, bu hükme karşı itiraz kanun yoluna başvurabileceğ $i$,

d) Teklifin kabulünün ancak müdafi huzurunda gerçekleştirilebileceği, seçtiği bir müdafi yoksa istemi aranmaksızın kendisine bir müdafi görevlendirileceği,

e) Mahkeme tarafindan hüküm kuruluncaya kadar her aşamada seri muhakeme usulünden vazgeçebileceği,

f) Mahkemece verilen hükmün adli siciline kaydedileceği,

g) Bu usulün uygulanmasını kabul etmediği takdirde genel hükümlere göre hakkında iddianame düzenlenerek kamu davası açılacă̆l,

g) Genel hükümlerin uygulanmasına geçilmesi halinde, seri muhakeme usulünü kabul ettiğine ilişkin beyanları ile bu usulün uygulanmasına dair diğer belgelerin, soruşturma ve kovuşturma işlemlerinde delil olarak kullanılamayacă̆ hususlarını kapsar.

Kanuni düzenlemeye göre, savcı şüpheliye teklifte bulunurken, sadece seri muhakeme usulünün uygulanmasını kabul edip etmediğini soracakmış gibi bir anlam çıkmaktadır. Ancak kendisi için talep edilecek cezanın ne olacağı hususunda şüpheliye bilgi verilmeksizin teklifte bulunulması anlamsız olacaktır. Nitekim kendisi için hangi cezanın talep edileceğini bilmeyen şüphelinin, teklifi kabul etmek konusunda çekimser kalması muhtemeldir. Bu nedenle kanunda yer almasa da Yönetmelikte, teklifte şüpheliye hangi yaptırımların uygulanacağının da anlatılacağı açıkça hükme bağlanmıştır. Bu bağlamda Yönetmelik m.10/2'de; “seri muhakeme usulünün uygulanması Cumhuriyet savcısı tarafindan şüpheliye teklif edilir; şüpheliye uygulanacak yaptırımların neler 
olduğu açıklanır" şeklinde bir düzenlemeye yer verilmiştir. Böylelikle şüpheli daha teklif yapılırken kendisi için istenecek cezayı ve/veya güvenlik tedbirini bilecek, cezanın seçenek yaptırımlara çevrilip çevrilmeyeceği ya da ertelenip ertelenmeyeceği yahut da HAGB uygulanıp uygulanmayacağı bilgisine sahip olacak ve buna göre karar verecektir. Dolayısıyla savcı seri muhakeme teklifini yapmadan önce mahkemeden talep edeceği cezayı ve diğer yaptırımları belirlemiş olmalıdır ki; şüpheliye bunu söyleyebilsin ${ }^{55}$. Ayrıca belirtmek gerekir ki; seri muhakeme usulünün uygulanmasına ilişkin C. savcısı tarafından şüpheliye yapılması öngörülen teklif ve öncesindeki bilgilendirmenin Ses ve Görüntü Bilişim Sistemi (SEGBİS) veya istinabe yollarıyla yapılması da mümkündür. ${ }^{56}$

Teklif yapılırken kişinin yanında müdafiin bulunması bir zorunluluktur. Eğer kendi seçmiş olduğu bir müdafi yoksa baro tarafından bir müdafi görevlendirilir (Yönetmelik m.10/3). Bu şekilde kanun koyucu, teklifin kanuna uygun şekilde yapıldığını, bu işlem sırasında bir avukatın varlığıyla teminat altına almak istemiştir.

Bununla birlikte, "seri muhakeme usulünün uygulanmasına ilişkin teklifin SEGBISS veya istinabe yoluyla yapıldığı hâllerde, şüphelinin seçtiği bir müdafii yoksa teklifin kabulünde hazır bulunması için müdafi görevlendirilmesi, istinabe evrakı gönderilen ya da SEGBIS ile dinleme talep edilen yer Cumhuriyet başsavcılı̆̆g tarafindan yapılır. Bu durumda soruşturmayl yürüten Cumhuriyet başsavcılı̆̆ tarafindan ayrıca bir müdafi görevlendirmesi yapılmaz (Yönetmelik m.11/3). ” Eğer şüphelinin kendi seçmiş müdafii yoksa ve baro tarafından müdafi görevlendirilmişse, teklif aşamasında görev alan bu müdafiin, hüküm verilmesi aşamasında da görev alması esası benimsenmiştir. Bu bağlamda "soruşturma evresinde görev yapan müdafi, mahkemede de öncelikle

55 Teklifin yapılmasında uygulanacak usul hakkında doktrinde ifade ve sorguya ilişkin usulün kıyasen uygulanması gerektiği yönünde görüşler bulunmaktadır. Bu konuda bkz. YAVUZ, 2020, s. 284; UĞURLUBAY / HAYDAR / KORKMAZ, 2019, s. 268.

56 Buna ilişkin Yönetmelik hükmüne göre; "soruşturmayı yürüten Cumhuriyet savcısı seri muhakeme usulüne ilişkin bilgilendirme ve teklifi SEGBIS veya istinabe yoluyla da yapabilir (Yönetmelik m.10/11)." Eğer savcı SEGBİS kullanacaksa, CMK m.38/A’ya göre gerekli işlemleri de yapar (Yönetmelik m.10/12). Bununla birlikte istinabeye başvurulacaksa, "soruşturmayı yürüten Cumhuriyet savcısı istinabe evrakına hazırlamış olduğu seri muhakeme usulü kabul tutanağını da ekler. İstinabe evrakının gönderildiği yer Cumhuriyet başsavcılığı bu Yönetmelikte belirtilen usule uygun olarak derhal davet işlemlerini yapar ve davete icabet eden şüpheliyi bu usul hakkında bilgilendirir. Şüphelinin müdafi huzurunda teklifi kabul etmesi halinde istinabe evrakl ekinde yer alan seri muhakeme usulü kabul tutanağl Cumhuriyet savcısı, şüpheli ve müdafii tarafindan imzalanır ve istinabe evrakl soruşturmayı yürüten Cumhuriyet başsavcılı̆̆ına gönderilir (Yönetmelik m.10/13).”, 
görevlendirilir Yönetmelik m.11/4).” Ancak müdafiin başka bir duruşmasının bulunması ya da sağlık sorunu yaşaması gibi zorunlu haller ortaya çıkarsa, ayrı müdafiler de bu safhalarda görev alabilir. Bu noktada, tek bir müdafiin iki ayrı safha için baro tarafindan görevlendirildiği hallerde, her safha için ücretlendirmenin ayrı ayrı mı olacağı yoksa tek ücret mi ödeneceği soruları akla gelebilir. İşin esası iki ayrı aşamada görev alan kimsenin iki ayrı ücretlendirmeye tabi olmasını gerektirir. Bu durum yerinde olarak bakanlık tarafından da kabul edilmiş ve tek bir müdafiin iki ayrı safhada görev alması durumunda ücretlendirmenin her bir safha için ayrı ayrı yapılacağı öngörülmüştür. Buna ilişkin Bakanlık yazısı ilgili C. Başsavcılıklarına gönderilmiştir.

“Şüphelinin teklifi reddetmesi hâlinde Cumhuriyet savcısı tarafindan buna ilişkin tutanak düzenlenerek soruşturma dosyasına eklenir (Yönetmelik m.10/10). ” Bu durumda muhakeme artık genel esaslara göre yürütülecektir. Ancak teklifi reddeden şüpheli sonradan iddianamenin düzenlenmesine kadar savcılığa başvurarak hakkında seri muhakeme usulü uygulanmasını sağlayabilir ${ }^{57}$. Bu husus yönetmelikte şu şekilde hükme bağlanmıştır; "şüpheli, iddianamenin düzenlenmesine kadar Cumhuriyet savcısına başvurarak hakkında seri muhakeme usulünün uygulanmasını talep edebilir. Bu durumda Cumhuriyet savcısı tarafindan seri muhakeme usulü uygulanır (Yönetmelik m.5/11)." Bununla birlikte teklif üzerine şüpheli düşünmek için süre de isteyebilir. Nitekim Yönetmelik m.10/3’te; “... talebi hâlinde teklifi değerlendirmesi için şüpheliye bir ayı aşmamak üzere makul bir süre verilir...” denilmektedir ${ }^{58}$. Burada şüpheliye makul bir süre verilmesi öngörülmüştür. Söz konusu süre hiçbir koşulda bir ayı aşamaz. Şüpheli bu süre sonunda herhangi bir mazeret bildirmeksizin gelmez yahut teklifi kabul etmediğini bildirirse seri muhakeme usulü uygulanmaz ${ }^{59}$.

“Şüphelinin teklifi kabul etmesi halinde buna ilişkin seri muhakeme usulü kabul tutană̆l (Yönetmelik Ek-1 Tutanağı) düzenlenir. Tutanakta; şüpheliye isnat edilen eylem, şüphelinin kabul beyanı, belirlenen sonuç ceza velveya güvenlik tedbiri ile

\footnotetext{
57 ŞAHIN / GÖKTÜRK, 2020, s. 205.

58 Yönetmelikteki bu hükmün hak kayıplarının önlenmesi için CMK m. 250/3'e ikinci bir cümle olarak eklenmesi gerektiği, hatta şüphelinin bu konuda talebi aranmaksızın bir haftadan az olmamak üzere bir süre verilmesi gerektiği yönünde bkz. TAŞKIN, 2020, s. 55 .

59 YAVUZ, 2020, s. 280 vd.
} 
uygulandı̆̆ı takdirde hükmün açıklanmasının geri bırakılması, seçenek yaptırım veya hapis cezasının ertelenmesine ilişkin hususlar yer alır. Kabul tutanağı Cumhuriyet savcısl ve şüpheli ile müdafi tarafindan imzalanır (Yönetmelik m.10/8). Bu durumda, kural olarak aynı gün içinde, talepname hazırlanarak görevli ve yetkili mahkemeye yönlendirilir (Yönetmelik m.10/9).

\section{Talep Safhası}

Cumhuriyet savc1sı müdafi huzurunda şüphelinin seri muhakeme usulünün uygulanmasını kabul etmesinden sonra, belirlediği yaptırıma hükmedilmesini, öngörmüşse bunun aynı zamanda seçenek yaptırımlara çevrilmesini, ertelenmesini veya HAGB'ye konu olmasını mahkemeden ister ${ }^{60}$. Ayrıca şüpheli hakkında güvenlik tedbiri uygulanması gerekiyorsa, bu husus da istemin içerisinde yer alır. Cumhuriyet savcısı bu istemlerini görevli ve yetkili mahkemeden "talepname" denilen bir tutanakla talep eder" $\mathrm{Bu}$ bağlamda talepname, görevli ve yetkili mahkemeye hitaben düzenlenir.

Görevli ve yetkili mahkeme konusunda Kanun'da bir düzenleme bulunmazken Yönetmeliğin tanımlar başlıklı 4. maddesinde mahkemeden anlaşılması gerekenin yetkili asliye ceza mahkemesi olduğu hüküm altına alınmıştır. Hakimler Savcılar Kurulu (HSK) Birinci Dairesi ise 02.01.2020 tarihinde almış olduğu karar ile seri muhakeme usulünü uygulayacak olan asliye ceza mahkemelerinin belirlenmesi ve böylece taleplerin yalnızca ayrıca belirlenmiş olan ihtisas mahkemelerince karara bağlanacağını öngörmüştür ${ }^{62}$.

CMK m.250/8'de kanun koyucu bu hususu şu şekilde hükme bağlamıştır; “Cumhuriyet savcısı, şüpheli hakkında seri muhakeme usulünün uygulanmasını yazılı

60 "Bu fikra hükmüne bakıldığında, seri muhakeme usulünü uygulayan aslen, görevli mahkemedir. Savcı bunun hazırlıklarını yapmakla görevli bir unsur gibi gözükmektedir. Ancak devamındaki 9. Fıkraya göre, savcını talebini kabul halinde savcının talebinde belirttiği cezaya hükmedilebileceği şeklindeki düzenleme bu görüşü değiştirmektedir. Bu nedenle savcının ceza veya yaptırımlarla ilgili talebi önem taşımaktadır.” Bkz. KIZILARSLAN, 2019, s. 1938.

61 Talepnamenin seri muhakemeyi kovuşturma evresine intikal ettiren bir ara süreç olduğu yönün bkz. TAŞKIN, 2020, s. 62 vd. Seri muhakeme usulü tamamlanıncaya kadar failin sıfatının şüpheli olduğu; talepnamenin görevli mahkemeye sunulmasının şüphelinin sıfatını değiştirmeyeceği yönünde bkz. CENTEL / ZAFER, 2020, s. 619.

${ }^{62} \mathrm{https} / /$ www.hsk.gov.tr/Eklentiler/files/02_01_2020\%20tarihli\%20ve\%201\%20say\%c4\%b11\%c4\%b1\% 20karar.pdf (erişim tarihi 07.07.2020). 
olarak görevli mahkemeden talep eder. ” Talepnamenin ne şekilde olacağına ilişkin Ek-2 örneği Yönetmelik ekinde yer almaktadır.

\section{6. İnceleme Safhası}

Mahkeme bir uyuşmazlığa ilişkin savcılığın kendisine gönderdiği talepname üzerine, bir gün ve saat belirleyerek şüpheli ve müdafini huzuruna çağırır. "Mazeretsiz olarak mahkemeye gelmemesi halinde, şüpheli bu usulün uygulanmasından vazgeçmiş sayılır (Yönetmelik 13/5).” Daha önce de belirttiğimiz üzere şüpheli seri muhakemenin her aşamasında, hüküm verilinceye kadar bu usulün uygulanmasından vazgeçme imkanına sahiptir (Yönetmelik m.5/4). Bu bağlamda teklifi kabul etmesine rağmen, mahkemenin davetine icabet etmeyen şüphelinin de bu usulden vazgeçmiş sayılacağ hüküm altına alınmıştır ${ }^{63}$. Mahkemeye davet edilen şüphelinin gelmemesi halinde usulden vazgeçmiş sayılacağı konusunda aydınlatılması gerekir. Bu bakımdan davetiyede gelmemesi halinde seri muhakeme usulünün uygulanmasından vazgeçmiş sayılacağ1 açıkça yazılmalıdır ${ }^{64}$. Vazgeçme halinde soruşturma genel hükümlere göre yürütülecektir.

Burada şüpheli ve müdafiin mahkeme huzuruna çıkması, klasik anlamda bir duruşmayı anımsatsa da incelemede gerçekleştirilen faaliyet bir duruşma değildir ${ }^{65}$. Nitekim duruşma tarafların katılımı ile kolektif olarak uyuşmazlık konusu olayın çözümüne ilişkin yapılan bir faaliyettir. Burada Cumhuriyet savcısı ve mağdurun mahkeme huzurundaki bu faaliyette yer alması söz konusu değildir ${ }^{66}$. Ayrıca mahkeme

63 Bir görüşe göre; şüphelinin mazeretsiz olarak mahkemeye çıkmadığı hallerde herhangi bir usulü hataya yol açmamak adına, kamu davasının ertelenmesi koşullarının oluşup oluşmadığı ikinci kez irdelenmeli, koşulların oluştuğu kanaatine varılır ise şüpheli hakkında CMK m. 171 uyarınca kamu davasının açılması ertelenmelidir. Bu görüşe göre, şüpheli hakkında ikinci kez inceleme yapılmaksızın iddianame hazırlanması hukuka aykırı olacaktır. TAŞKIN, 2020, s. 23.

64 ALDEMIR, 2019, s. 161 vd.

65 KEZER söz konusu faaliyeti duruşma olarak nitelendirmektedir. Bkz. KEZER, 2019, s. 56. Mahkemece karar verileceğinden, hakim işlemlerinden farklı bir şekilde mahkemenin duruşma açarak karar vermesi gerektiği yönünde bkz. KIZILARSLAN, 2019, s. 1941.

66 "Burada bir yargllama işlemi ve duruşma söz konusu olmadiğl için şüpheli dışında herhangi bir kimsenin dinlenmesi gerekmemektedir... Mahkeme, yapacă̆l değerlendirmede şüpheli dışında herhangi bir kimsenin de dinlenmesini gerekli görecek olursa soruşturmanın genel hükümlere göre sonuçlandırılması için talebi reddetmelidir.” YAVUZ, 2020, s. 292. “...seri muhakeme sürecinin hiçbir aşamasına mağdur ya da suçtan zarar görenin katılması mümkün değildir.” ERDEM / ŞENTÜRK, 
de sadece seri muhakeme usulüyle ilgili şüpheliyi müdafi huzurunda dinleme ve bu usulün kanunda belirlendiği şekliyle hukuka uygun uygulanıp uygulanmadığını denetleme yetkisine sahiptir (Yönetmelik m.13/1). Bunun yanında ayrıca şüphelinin gerçekten suç işleyip işlemediği konusunda bir araştırma ya da değerlendirme yapma yetkisi bulunmamaktadır. Şüphelinin dinlenmesi yalnızca seri muhakeme usulüne ilişkin kapsamla sınırlıdır. Bu bağlamda mahkeme, şüpheliye suçun sübutuna ilişkin bir soru yöneltemez ${ }^{67}$. Nitekim 250. maddenin gerekçesinde de hakimin faili dinleyeceği, seri muhakeme usulüne uygun düştüğü ölçüde duruşmaya ilişsin usul hükümlerini uygulayabileceği; ancak duruşmanın ertelenmesi ya da delil araştırması sonucunu doğurabilecek bir tercihte bulunamayacağı belirtilmiştir ${ }^{68}$.

Ayrıca vurgulamak gerekir ki; seri muhakemedeki inceleme safhası ve hatta aşağıda inceleyeceğimiz hüküm kurma safhası, hala ceza muhakemesinin soruşturma aşamasında gerçekleştirilen bir faaliyettir ${ }^{69}$. Mahkemeye talepnamenin iletilmesi ve onun şüpheli ve müdafini çağırması her ne kadar kovuşturmaya geçildiği izlenimi verse de mahkeme hükmünü kuruncaya kadar hala soruşturma devam etmektedir. Kanuni düzenlemede de bu aşamada isnat altında bulunan kimseden sürekli şüpheli olarak bahsedilmesi bu durumu desteklemektedir (Bkz. CMK m.250/9; Ayrıca bkz. Yönetmelik m.13/1). Mahkeme hükmünü verdikten sonra kovuşturma aşaması başlayacak, süresi içinde itiraza başvurulmasıyla ise kovuşturmanın kanun yolu devresine geçilecektir. Seri muhakemede hükme karşı öngörülen kanun yolu aşağıda daha ayrıntılı ele alınacağından,

2020, s. 589. Aksi görüşe göre; seri muhakeme usulünde şüpheli dışında herhangi bir kimsenin dinlenmesi gerektiğine ilişkin bir kural yoksa da mağdurun dinlenmesi yasaklayıcı bir hükümle engellenmiş de değildir. Mağdur ve müşteki konumunda bulunanların bu usulde dinlenmemesi hak ihlallerine neden olabileceği gibi CMK'nın katılmaya ilişkin hükümleri bu nedenle anlamını yitirecektir. Bu görüş sahibine göre; mağdur ve müştekinin mutlaka dinlenmesi, şikayetçi iseler katılma hususunda beyanlarının alınması gerekir. Bkz. ALDEMIR, 2019, s. 162. Benzer değerlendirmeler için bkz. KEZER, 2019, 57 vd. Seri muhakeme usulünde suçtan zarar görenin hiçbir menfaatinin korunmadığı yönünde bkz. YENISEY / NUHOĞLU, 2020, s. 844. Kanaatimizce kanuni düzenlemeden böyle bir sonuca varılması mümkün görünmemektedir. Böyle bir uygulama yapmak özel bir muhakeme usulü olan seri muhakemenin amacına aykırı olacaktır.

67 YAVUZ, 2020, s. 292.

68 Aynı yönde bkz. UĞURLUBAY / HAYDAR / KORKMAZ, 2019, s. 272.

69 Aynı yönde; “...bu usulde mahkeme tarafindan gerçekleştirilen işlemler bütünü, savcılık tarafindan yapılan talep hakkında kendine özgü bir tür inceleme ve onay işleminden ibaret olup soruşturma evresine dahildir." Bkz. YAVUZ, 2020, s. 288. "Mahkeme önündeki inceleme ve karar verme süreci soruşturma evresi içinde düşünülmelidir.” Bkz. ŞAHİN / GÖKTÜRK, 2020, s. 208. 
burada daha fazla ayrıntıya girmemeyi uygun bulmaktayı.

Mahkeme talepnameyi aldıktan sonra inceleme yapacaktır. Bu husus Yönetmelik m.13'te hükme bağlanmıştır. Buna göre; “mahkeme, talepnamenin verildiği gün incelemesini derhal yapar, şüpheliyi müdafi huzurunda seri muhakeme usulü ile ilgili olarak dinler ve usulü sonuçlandırır. Şüphelinin seri muhakeme usulü hakkında dinlenmesi SEGBİS veya istinabe yoluyla da yapılabilir (Yönetmelik m.13/1). Görüldüğü üzere yönetmelikte seri muhakemenin seri ve hızlı şekilde yapılması için açık düzenlemeye yer verilmiş; mahkemenin incelemeyi, talepnamenin verildiği gün derhal yapmasını hüküm altına alınmıştır. Yukarıda incelediğimiz ve hatırlanacağı üzere, teklif aşamasına ilişkin Yönetmelik m.10/9'da şüphelinin teklifi kabul etmesi halinde aynı gün mahkemeye yönlendirileceği hükme bağlanmıştır. Bu bağlamda seri muhakeme usulünün kanun yoluna kadar olan aşamalarının bir-iki gün içerisinde bitirilmesi amaçlanmıştır ${ }^{70}$.

Ayrıca CMK m.250/9 ve Yönetmelik m.13/1 düzenlemeleriyle, teklifte olduğu üzere, inceleme sırasında şüpheli dinlenirken, ona gerekli hukuki desteğin sağlanması ve bir müdafiin işlemlerin hukuka uygunluğunu denetlemesi zorunlu kabul etmiştir. Dolayısıyla inceleme sırasında şüpheli dinlenirken bir müdafiin hukuki yardımından yararlanması zorunludur. Kendi seçmiş olduğu müdafi yoksa baro tarafindan bir müdafi görevlendirilecektir. Türkçeyi etkin olarak konuşamayan ya da engeli nedeniyle faaliyete etkin olarak katılamayan şüpheliye tercüman veya çevirmen atanmasına ilişkin teklif aşamasında aktardığımız hususlar, bu safha için de geçerlidir (Yönetmelik m.5/5).

İnceleme sonucunda mahkeme üç farklı karar verebilecektir. Bunlar (Yönetmelik m.13/2, m.13/4, m.14); 1) Eksikliklerin giderilmesi amaciyla talepnamenin mahkemeye gönderilmesi kararı (Talepnamenin iadesi) 2) Talepnamenin reddi kararı 3) Talepname doğrultusunda kurulacak hüküm.

70 Aynı yönde bkz. YILMAZ / APISŞ, 2020, s. 81. Talepnamenin aynı gün içerisinde incelenip karar verilmesinin adil yargılanmak hakkı bakımından sorun yaratabileceği; CMK m. 174/1'deki iddianamenin iadesi için tanınan on beş günlük süre de olduğu gibi mahkemeye talepnameyi incelemek üzere kısa da olsa bir süre tanınmasının daha yerinde olacağı yönünde bkz. TAŞKIN, 2020, s. 64,76. 


\section{Hüküm Kurulması Safhası}

Mahkeme talepnameyi incelendikten sonra, o ana kadar süreçte seri muhakeme usulünün hukuka uygun şekilde uygulandığını tespit ederse, talepname doğrultusunda cezaya ve/veya güvenlik tedbirine mahkumiyet hükmünü kurar (CMK m.250/9) ${ }^{71}$. Bu husus yönetmelikte şu şekilde düzenlenmiştir; "mahkeme, eylemin seri muhakeme usulü kapsamında olduğu, bu usulün şüpheliye Kanunda öngörülen koşullar çerçevesinde teklif edildiği ve şüphelinin bu teklifi müdafii huzurunda özgür iradesiyle kabul ettiği kanaatine varırsa talepte belirlenen yaptırım doğrultusunda hüküm kurar (Yönetmelik m.14/1)."

Görüldüğü üzere mahkeme şartların oluştuğunu tespit ettiğinde talepte belirlenen yaptırım doğrultusunda hüküm kuracaktır. Mahkemenin belirlenen yaptırımı değiştirmek gibi bir yetkisi bulunmamaktadır ${ }^{72}$. Ayrıca esasa ilişkin değerlendirme yapma yetkisi bulunmamaktadır. Bunun dışında savcılığın TCK m.61/1'e göre ceza hesaplarken alt ve üst sinırlar arasında temel cezayı belirlerken takdir yetkisini uygun kullanıp kullanmadığını da denetleyemez. Nitekim bu husus münhasıran savcılığın takdirindedir. Buna karşın alt sınırın altında veya üst sınırın üstünde bir ceza takdiri varsa, bu husus cezanın belirlenmesinde maddi hata kapsamında değerlendirilip, talepnamenin iadesine karar verilecektir.

Son olarak belirtmek gerekir ki; kurulan "hüküm; varsa mă̆dur, suçtan zarar gören veya genel hükümlere göre katılma hakkını haiz olan kişilere tebliğ edilir (Yönetmelik m.14/2). Tebligatın yapılması, aşağıda inceleyeceğimiz üzere, seri muhakeme sonunda verilen hükme karşı kabul edilen itiraz kanun yoluna başvuracakların (Bkz. CMK m.260) birçoğu bakımından bildirimin yapılması ve yedi günlük itiraz süresinin başlaması sonucunu doğuracağından, özel önem arz etmektedir.

\section{Kanun Yolu Safhası}

Seri muhakeme sonucunda kurulan hükme karşı itiraz kanun yoluna başvurulabilir.

71 Talepnamenin kabulü ile hüküm kurulmasının Türk ceza muhakemesi hukukunda yeni bir soruşturmayı sonlandıran hal olduğu yönünde bkz. KIZILARSLAN, 2019, s. 1943.

72 DEĞİRMENCİ, 2020, s. 22; ERDEM / ŞENTÜRK, 2020, s. 596; ŞAHİN / GÖKTÜRK, 2020, s. 206; YAVUZ, 2020, s. 294 vd. Mahkemenin yalnızca talepname doğrultusunda hüküm kurabilmesinin başta mahkemelerin bağımsızlığı olmak üzere pek çok ceza muhakeme ilkesi ile çelişki yarattığı yönünde bkz. KIZILARSLAN, 2019, s. 1942 vd.; TAŞKIN, 2020, s. 66. 
Nitekim CMK m.250/14’te “dokuzuncu fikra kapsamında Cumhuriyet savcisinın talebi doğrultusunda mahkemece kurulan hükme itiraz edilebilir.” denilmek suretiyle, söz konusu hükümlere karşı itiraz edilebileceği açıkça düzenleme altına alınmıştır. Benzer şekilde, Yönetmelik m.15’te; “mahkemece Yönetmeliğin 14 üncü maddesinin birinci fikrası kapsamında Cumhuriyet savcısının talebi doğrultusunda kurulan hükme genel hükümler çerçevesinde itiraz edilebilir" şeklinde bir hükme yer verilmiştir. Kanun'da da açıkça belirtildiği gibi yalnızca seri muhakeme sonucunda kurulan hükümlere karşı itiraz yoluna gidilebilir. Talepnamenin reddi kararlarına itiraz edilemez ${ }^{73}$.

Normalde ilk derece mahkemeleri tarafından verilen hükümlere karşı başvurulabilecek kanun yolu istinaftır (CMK m.272/1). İtiraz ise kural olarak hakimlik kararlarına, kanunun açıkça öngördüğü hallerde ise mahkeme kararlarına karşı öngörülmüş olağan bir kanun yoludur (CMK m.267) ${ }^{74}$. Mahkeme hükümlerine karş1 yukarıda da belirttiğimiz üzere istinafa başvurulabildiğinden, CMK m.267'de belirtilen ve kanunun açıkça belirttiği hallerde itiraz incelemesine konu olabilen mahkeme kararları ise kural olarak ara kararlardır. Ancak kanun koyucu burada genel kuraldan ayrılarak bir hükme karşı itiraz yolunu kabul etmiştir ${ }^{75}$. Seri muhakeme usulü sonucunda asliye ceza mahkemesince kurulan hükümlere karşı yalnızca itiraz kanun yoluna başvurulabilir. İtiraz üzerine verilen karar kesin olup; istinaf ve temyiz yoluna gidilmesi mümkün değildir ${ }^{76}$.

İtiraz süresi ise hükmün bildirilmesinden itibaren yedi gündür (CMK m.268/1). İtiraz incelemesini yapacak merci ise CMK m.268/3'teki genel kurallara göre

73 DEĞİRMENCİ, 2020, s. 22; ERDEM / ŞENTÜRK, 2020, s. 597.

74 Bir görüşe göre itiraz kanun yolunun öngörülmüş olması seri muhakeme usulünde verilen kararların hakim kararı niteliğinde olduğunu bunun yanı sıra kanun yoluna ilişkin işlemlerin de hızlandırılmak istendiğini göstermektedir. Bkz. KIZILARSLAN, 2019, s. 1944.

75 “ 'CMK'da, hükme karşı istinaf kanun yoluna başvurulacağına dair genel kuralın iki istisnasında biri (ikincisi ise basit yargılama usulündedir) burada karşımıza çıkmaktadır.” Bkz. ERSOY, 2020, Uğur, "Seri Muhakeme ve Basit Yargılama Usullerinde İtiraz Kurumuna İlişkin Sorunlar ve Çözüm Önerileri”, Selçuk Üniversitesi Hukuk Fakültesi Dergisi, Yıl: 2020, Cilt: 28, Sayı: 2, s. 861. “...mahkemenin sonkararı niteliğinde olan hükme karşı istinaf değil itiraz yolunun kabul edilmesi, seri muhakeme usulüne özgü bir durumdur.” Bkz. ŞAHIN / GÖKTÜRK, 2020, s. 206. “Aslinda itiraz kanun yolu hakimlik makamı kararlarına karş̧ kabul edilmiş bir kanun yoluyken burada itiraz edilebilen bir mahkeme kararı daha görüyoruz.” Bkz. YENISEY / NUHOĞLU, 2020, s. 845.

76 YAVUZ, 2020, s. 302. 
belirlenecektir. İtiraz başvurusu yazılı veya tutanağa geçirilmek suretiyle sözlü şekilde, hükmü veren mahkemeye yapılacaktır (CMK m.268/1). Hükmü veren mahkemenin üç gün içinde hükmünü itirazda belirtilen hususlara bağlı olarak düzeltme veya yine aynı süre içinde inceleme merciine göndermesi gerekir (CMK m.268/2). Seri muhakeme sonucunda kurulan hükme kimlerin itiraz edebileceği hususunda da bir ayrı bir belirleme yapılmadığından, genel muhakeme usulünde itiraz yoluna kimler başvurabiliyorsa onların itiraz edebileceği sonucuna varılmalıdır. Bu kimseler ise CMK'nın 260 ila 262. maddelerinde sayılmıştır ${ }^{77}$.

Hukuk sistemimizde itiraz yolunun bu kanun yolunun yapısına uymayan kararlar bakımından kabul edilmesine ilişkin başka örnekler de vardır. Örneğin HAGB kararlarına itiraz edilmesi de birçok uygulama problemine neden olmuştur. Ancak her ne kadar açık kanuni düzenleme gereği, HAGB kararlarına karşı itiraz yoluna başvurulabiliyorsa da en azından burada hükme değil; bir tür ara karar olan HAGB kararına karşı bu yol kabul edilmiştir. Bununla birlikte HAGB’ye itiraz edildiğinde itiraz merciinin yapacağ incelemenin kapsamının ne olacağı, hükmün esasına girip girmeyeceği gibi konularda birçok farklı görüş ortaya çıkmış ve süreç içerisinde birçok içtihat değişikliği de yaşanmıştır. Benzer problemlerin hükme karşı kabul edilen bu itiraz yolunda da yaşanması muhtemeldir ${ }^{78}$.

\section{E. Seri Muhakeme Usulüne İlişkin Belge ve Beyanlara Özgü Delil Değerlendirme Yasağı}

Kanun koyucu, seri muhakeme usulünün uygulanma sürecinde, özellikle şüphelinin süreçte kullanacağı ifadelerle ve süreç içerisinde ortaya çıkabilecek belgelerle ilgili tedirginlik yaşamaması için bu usule özgü bir delil değerlendirme yasağı getirerek,

77 Bir görüşe göre; seri muhakeme usulünün uygulanabileceği suç tiplerinde doğrudan doğruya bir kişinin mağduriyeti söz konusu olmadığından, seri muhakeme usulü sonucunda kurulan hükme itiraz etme yetkisinin pratik olarak Cumhuriyet savcısı, şüpheli ve müdafii, şüphelinin eşi ve kanuni temsilcisine ait olduğu söylenebilir. Bkz. ERSOY, 2020, s. 861.

78 Benzer değerlendirmeler için bkz. ERSOY, 2020, s. 862; YURTCAN, 2019, s. 719, BAYTAZ, 2020, s. 37 vd. Hükmün açıklanmasının geri bırakılmasında itirazın kapsamına ilişkin bkz. ÖZBEK, Veli Özer / MERAKLI, Serkan, "Hükmün Açıklanmasının Geri Bırakılması Kararına İtiraz Üzerine Yapılacak Denetim, Marmara Üniversitesi Hukuk Araştırmaları Dergisi, Yıl: 2013, Cilt: 19, Sayı: 2, s. 221-236. 
şüphelinin süreç içerisinde rahat davranabilmesini teminat altına almak istemiştir ${ }^{79}$. Bu bağlamda "seri muhakeme usulünün herhangi bir sebeple tamamlanamamass veya soruşturmanın genel hükümlere göre sonuçlandırllması amacıyla Cumhuriyet başsavcılı̆̆ına gönderilmesi hâllerinde, şüphelinin seri muhakeme usulünü kabul ettiğine ilişkin beyanları ile bu usulün uygulanmasına dair diğer belgeler, takip eden soruşturma ve kovuşturma işlemlerinde delil olarak kullanılamaz (CMK m.250/10; Ayrıca bkz. Yönetmelik m.5/8).”

Belirtmek gerekir ki Kanunen delil olarak kullanılması yasaklananlar şüpheli hakkında seri muhakeme usulünün uygulanmasına başlanmasıyla ortaya çıkanlardır. Seri muhakeme usulünün uygulanmasına safhasından önce soruşturma esnasında elde edilen deliller bakımından bu yasak geçerli değildir ${ }^{80}$.

\section{GENEL OLARAK ADİL YARGILANMA HAKKI}

Hukuki anlamda hak, hukuken bir şeyi yapmaya yetkili olmak ya da bir şeyi talep edebilmektir. İnsan hakları kavramı ise, insanların doğarken bir takım haklarla beraber doğdukları ve bunlara devlet tarafından müdahale edilemeyeceği düşüncesinin bir tezahürü olarak XVII. yüzyılda ortaya çıkmıştır. Bu bağlamda insan hakları kavramı hukuktan değil, ahlakilik düşüncesinden kaynaklanır ve ahlaki bir takım değerleri ifade eder. İnsan haklarını, insanlığın belirli bir gelişme çağında teorik olarak bütün insanlara tanınması gereken ideal değerler listesi olarak tanımlayacak olursak; temel haklar terimi, insan hakları denilen ideal listenin devlet tarafından tanınmış bölümünü ifade eder. Temel bir hak olarak adil yargılanma hakkı ise, sanık bakımından yargılamanın uluslararası sözleşmelerle belgelenmiş ilkelere uygun bir şekilde yapılmasını ve onun muhakemeye ilişkin haklarının korunmasını teminat altına alır.

79 Seri muhakemede şüpheli itiraf ve suçu kabul baskısı altında olduğundan, seri muhakeme usulünün sonuca ulaşamadığı durumlarda süreç sırasında verdiği beyanlarından ve bu sırada elde edilen delillerden sorumlu sayılmamasının doğru olduğu yönünde bkz. KIZILARSLAN, 2019, s. 1944.

80 ERDEM / ŞENTÜRK, 2020, s. 584,595. 
Anayasanın 36. maddesinde açıkça teminat altına alınan adil yargılanma hakkı, birçok yazar tarafından, Anayasanın 2. maddesinde hükme bağlanan hukuk devleti ilkesinin de bir gereği olarak kabul edilmektedir ${ }^{81}$. Söz konusu hak 1948 tarihli İnsan Hakları Evrensel Bildirgesinin 10. maddesinde hükme bağlandığı gibi, Türkiye'nin taraf olduğu temel hak ve özgürlüklere ilişkin uluslararası sözleşmelerden olan Avrupa İnsan Hakları Sözleşmesi'nin (AİHS) 6. maddesinde, Birleşmiş Milletler Medeni ve Siyasal Haklar Sözleşmesi'nin ise 14. maddesinde bireyler bakımından teminat altına alınmıştır. Bunun dışında cezai uyuşmazlıklara ilişkin olarak, CMK' da da adil yargılanma hakkına ilişkin birçok husus hükme bağlanmıştır.

$\mathrm{Bu}$ bağlamda iç hukukumuzda ceza muhakemesi bakımından adil yargılanma hakkının kaynakları; Anayasa, Avrupa İnsan Hakları Sözleşmesi, Birleşmiş Milletler Medeni ve Siyasal Haklar Sözleşmesi ile Ceza Muhakemesi Kanunu'dur. Bu kaynaklar arasında AİHS’nin özel bir önemi vardır. Bu önem iki hususa dayanmaktadır. Öncelikle 2004 yılında Anayasa'nın 90. maddesine eklenen hükümle, bir hukuki bir sorunun çözümü sırasında, usulüne uygun olarak yürürlüğe girmiş olan temel hak ve hürriyetlere ilişkin uluslararası sözleşme hükümleriyle kanun hükümleri arasında bir uyuşmazlık olduğu anlaşılırsa, uyuşmazliğın temel hak ve hürriyetlere ilişkin uluslararası sözleşmenin hükümlerine göre çözüleceği düzenlenmiştir. Her ne kadar adil yargılanma hakkını veya onun içeriğinde yer alan alt hakları teminat altına alan başkaca uluslarası sözleşmeler olsa da, AİHS'ni bunlar arasında daha özel bir konuma getiren ikinci husus, başvurular sonucunda taraf devletlerin sözleşme hükümlerine uygun davranıp davranmadıklarını denetleyen bir yargılama mekanizmasının (Avrupa Insan Hakları Mahkemesinin (AIHHM)) bulunmasıdır. Bu bağlamda adil yargılanma hakkına ilişkin yapacağımız açıklamalar AİHS hükümleri göz önünde bulundurularak yapılacaktır.

Adil yargılanma hakkı AİHS'nin 6. maddesinde üç fıkra halinde düzenlenmiştir. 6. maddenin Türkçe çevirisi şu şekildedir: ${ }^{82}$

81 Hukuk devletinde bireylere sağlanması gereken minimum garantiler için bkz. HEINRICH, Bernd, "Rechtsstaatliche Mindestgarantien im Strafverfahren", Juristische Ausbildung, Y1l: 2003, Cilt: 35, Say1: 3, (s. 167- 173).

82 https://www.echr.coe.int/Documents/Convention_TUR.pdf (erişim tarihi 17.09.2020) 


\section{Madde 6: Adil yargilanma hakkı}

1. Herkes, gerek medeni hak ve yükümlülükleriyle ilgili nizalar, gerek cezai alanda kendisine yöneltilen suçlamalar konusunda karar verecek olan, yasayla kurulmuş, bağımsız ve tarafsız bir mahkeme tarafından davasının makul bir süre içinde, hakkaniyete uygun ve açık olarak görülmesini isteme hakkına sahiptir. Hüküm açık oturumda verilir; ancak, demokratik bir toplumda genel ahlak, kamu düzeni ve ulusal güvenlik yararına, küçüklerin korunması veya davaya taraf olanların özel hayatlarının gizliliği gerektirdiğinde veya davanın açık oturumda görülmesinin adaletin selametine zarar verebileceği bazı özel durumlarda, mahkemenin zorunlu göreceği ölçüde, duruşmalar dava süresince tamamen veya kısmen basına ve dinleyicilere kapalı olarak sürdürülebilir.

2. Bir suç ile itham edilen herkes, suçluluğu yasal olarak sabit oluncaya kadar suçsuz sayılır.

3. Her sanık en azından aşağıdaki haklara sahiptir:

a) Kendisine yöneltilen suçlamanın niteliği ve nedeninden en kısa zamanda, anladı̆̆ bir dille ve ayrıntılı olarak haberdar edilmek;

b) Savunmasını hazırlamak için gerekli zamana ve kolaylıklara sahip olmak;

c) Kendi kendini savunmak veya kendi seçeceği bir avukatın yardımından yararlanmak ve ĕger avukat tutmak için mali olanaklardan yoksunsa ve adaletin selameti gerektiriyorsa, mahkemece görevlendirilecek bir avukatın para ödemeksizin yardımından yararlanabilmek;

d) İdia tanıklarını sorguya çekmek veya çektirmek, savunma tanıklarının da iddia tanıklarıyla aynı koşullar altında çağrılmasının ve dinlenmesinin sağlanmasını istemek;

e) Duruşmada kullanılan dili anlamadığı veya konuşmadı̆̆ takdirde bir tercümanın yardımından para ödemeksizin yararlanmak.

$\mathrm{Bu}$ düzenleme 1 şı̆̆ında adil yargılanma hakkı şu şekilde tanımlanabilir; bireyin, gerek medeni hak ve yükümlülüklerine gerekse cezai alanda kendisine yöneltilen

İngilizce metin için bkz. https://www.echr.coe.int/Documents/Convention ENG.pdf (erişim tarihi 17.09.2020) 
suçlamalara ilişkin herhangi bir davanın, yasayla kurulmuş, bağımsız ve tarafsız bir mahkeme tarafindan, makul bir süre içerisinde, aleni ve hakkaniyete uygun olarak görülmesine ilişkin hakkıdır ${ }^{83}$.

AİHS'nin 6. maddesinde belirtilen hak ve ilkeler madde metninde de açıkça ifade edildiği üzere tüm cezai ve medeni muhakemeler bakımından geçerlidir. Ancak medeni ve cezai muhakeme tabirinden içeriği, taraf devletlerin iç hukuklarında söz konusu uyuşmazlığı hangi muhakeme dalına ait kabul ettiklerine göre tespit edilmez. Bilakis AİHM'nin bu konuya ilişkin geliştirdiği kıstaslara göre uyuşmazlığgn hangi muhakeme dalına ait olduğuna bakılır. Bu itibarla bazı durumlarda bu hak ve ilkeler disiplin soruşturmaları bakımından da önem arzetmektedir. Şöyle ki, eğer disiplin soruşturması sonucunda faile, önemli derecede ağır bir özgürlüğü bağlayıcı ceza veriliyorsa, iç hukukta bu faaliyetin idari bir soruşturma olarak nitelendirilmesine önem vermeyen AİHM, bu durumda da 6. maddenin gereklerinin bireye tanınması gerektiği kanaatindedir.

Ceza muhakemesi açısından 6. maddenin lafzına bakıldığı zaman, burada söz konusu olan hakların, sadece mahkeme önünde gerçekleştirilen muhakeme faaliyeti sırasında uygulanan, dolayısıyla sadece kovuşturma sırasında geçerli olan birer ilke oldukları sonucuna ulaşılacaktır. Eğer AİHM de sadece maddenin lafzına bakarak hareket etmiş olsaydı, sanık hakları en fazla Cumhuriyet savcısı ve kolluk tarafından yürütülen soruşturma sırasında ihlal edildiği için, güvencenin çok fazla bir anlamı kalmayacaktı. Çünkü duruşma alenidir ve aleniyetin getirdiği bir denetleme vardır. Ancak soruşturma evresi bakımından aynı şeyler söylenemeyecektir. Bu nedenlerle AİHM verdiği çeşitli kararlarda, sözleşmede yer alan sanık kavramının iç hukuktaki anlamıyla değil,

83 Donay tarafından yapılan tanıma göre adil yargılama; yargılamanın olanaklar ölçüsünde gerçekleri yansıtabilmesi için, uyuşmazlığın tarafları arasında fiili ve hukuki bir fark gözetmeksizin, iddia ve savunmaların eşit ölçülerde ve karşılıklı olarak yapıldığı dürüst bir yargılamadır. Bkz. DONAY, Süheyl, İnsan Hakları Açısından Sanığın Hakları ve Türk Hukuku, İstanbul Üniversitesi Hukuk Fakültesi Yayınları, İstanbul, 1982, s.41; Schroeder ise yeterli müdafaa imkanları sağlanarak ve hile yapılmadan görülen davanın adil olduğunu kabul etmektedir. Bkz. SCHROEDER, 1999, s.6. Uluslararası Af Örgütünün adil yargılanma hakkına ilişkin yayınında ise, Adil bir yargılamanın olabilmesi için gerekli olan tüm şartların, adil yargılanma hakkının içeriğini oluşturduğu kabul edilmektedir. Bkz. Uluslararası Af Örgütü, Adil Yargılanma Hakkı, İletişim Yayınları, İstanbul, 2000, s.101. Birçok yazar da adil yargılanma kurumunu tarif edilmesi güç bir prensip olarak nitelendirmekte ve bu ilkenin ideal şartları oluşturma mecburiyeti olarak kabul edilmesi gerektiğini savunmaktadırlar. Bkz. SCHROEDER, 1999, s.10-11. 
sözleşmenin bütünü açısından özerk bir kavram olarak yorumlanması ve anlaşılması gerektiğine dikkati çekmiştir.

\section{AİHM IÇTIHHATLARI IŞIĞINDA ALTERNATIFF ÇÖZÜM YOLLARININ ADÍL YARGILANMA İLKESINE AYKIRILIĞI SORUNU}

\section{A. Genel Olarak}

Alternatif çözüm yolları bakımından genel muhakeme ilkelerinden önemli sapmalar olduğu bir gerçektir. Bu tür yollarda birçok kez maddi gerçeğin araştırılmasından ya da adil yargılanmaya ilişkin ilkelerden feragat edilerek ceza adaleti sisteminin hızlandırılmasına çalışılmaktadır. Hukukumuzda yakın zamana kadar sadece, önödeme, uzlaştırma, kamu davasının açılmasının ertelenmesi, hükmün açıklanmasının geri bırakılması gibi alternatif çözüm yollarına yer verilmişti. Bunlardan önödemenin uygulanabilmesi için şüphelinin, rızasıyla, tebligattan itibaren 10 gün içinde, teklifte belirtilen para miktarını devlet hazinesine yatırması gerekmektedir (bkz. TCK m.75). Uzlaştırmada ise şüphelinin uzlaştırma teklifini kabul etmesi gerekir ki, uzlaştırma girişiminde bulunulsun (CMK m.253). Bunun yanında hükmün açıklanmasının geri bırakılmasında (HAGB'de) sanığın bu kurumun uygulanmasına rıza göstermesi esastır (bkz. CMK m.231/5 vd.). Bu bağlamda söz konusu kurumlardan yalnızca kamu davasının açılmasının ertelenmesinde (bkz. CMK m.171/2 vd.) isnat altındaki kişinin kurumun uygulanmasına rıza göstermesi aranmamaktadır. Dolayısıyla isnat altında bulunan kimse, kamu davasının açılmasının ertelenmesi dışındaki tüm alternatif çözüm yollarının kendisi hakkında uygulanmasına engel olma imkanına sahiptir. Bununla birlikte kamu davasının açılmasının ertelenmesi de dahil bu kurumlardan hiçbirinde isnat altındaki kişi hakkında bir mahkumiyet hükmü söz konusu olmamaktadır. Önödeme ve uzlaştırma, soruşturma evresinde başarıyla sonuçlanırsa kovuşturmaya yer olmadığı kararı, istisnaen kovuşturmada başarıyla sonuçlanırsa da düşme kararı verilmektedir. Kamu davasının açılmasının ertelenmesinde şüpheli beş yıllık denetim süresi içerisinde yeni bir suç işlemezse kovuşturmaya yer olmadığı kararı verilmektedir. Söz konusu kurumun istisnaen de olsa kovuşturma uygulanma imkanı yoktur. HAGB'de ise sanık beş yıllık denetim süresi içerisinde yeni suç işlemezse hakkında düşme kararı verilmektedir. 
Ancak 2019 y1lında hukuk sistemimize giren seri muhakeme ve basit yargılama usulleriyle birlikte, alternatif çözüm yolları bakımından yukarıda aktarılan durumda ciddi bir değişiklik ortaya çıkmıştır. Nitekim söz konusu iki alternatif çözüm yöntemi sonunda isnat altındaki kimse hakkında mahkumiyet hükmü kurulabilmektedir. Bu bağlamda toplumumuz ilk kez, alternatif çözüm yöntemleri ile isnat hakkındaki kişiler hakkında mahkumiyet hükmü kurulmasına ilişkin yöntemlerle tanışmıştır. Ancak mahkemelerin iş yükününün azaltılamamasına ilişkin sorunlar, kanun koyucuyu başkaca devletlerde olduğu üzere bu iki kurumu ihdas etmeye yönlendirmiştir.

AİHM de bu tür alternatif çözüm yöntemleri ile isnat altındaki kimseler hakkında mahkumiyet hükmü kurulabilmesini AİHS'nin ve özellikle 6. maddede düzenlenen adil yargılanma hakkının bir ihlali olarak görmemektedir. Ancak bunun için birtakım koşulların gerçekleşmesini aramaktadır. Aksi takdirde ilgililerin adil yargılanma hakkı ihlal edilmiş olacaktır. Nitekim seri muhakeme ve basit yargılama gibi kurumlar adil yargılanma hakkı kapsamında yer alan alt haklardan birçoğunu ciddi anlamda ihlal etme potansiyeline sahiptir.

Bu noktada, AİHS'ye aykırı olmasa bile, anayasal hükümlerden kaynaklı olarak, bu tür kurumların anayasaya aykırılığı söz konusu olabilir mi? sorusu akla gelebilecektir. Kanaatimizce anayasanın temel hak ve özgürlükler arasında düzenlediği haklar bakımından, AİHM gibi düşünülerek, bir sonraki başlıkta açıklayacağımız koşulların varlığı durumunda, kişinin kendisine tanınan avantajları göz önünde bulundurarak; rızasıyla, somut olayda muhakemeye ilişkin temel hakları kullanmaktan vazgeçebileceğinin kabul edilmesi, hukuken makul bir düşünce tarzıdır. Bununla birlikte ilgili hak bakımından temel haklar dışında, anayasanın başka bölümlerinde de düzenleme getirilmişse, bir başka deyişle, anayasa koyucu söz konusu kişisel teminata, devletin yapısı ve kamusal düzen bakımından ayrıca bir önem atfetmişse, bu halde söz konusu hakka yapılacak müdahalenin, anayasaya aykırı olduğunun kabulü gerekir. Örneğin; şüpheden sanığın yararlanması, AY m.38'de hükme bağlanmış temel haklardandır. Ancak anayasa koyucu, bu teminatın sadece bireyler bakımından önem arz etmediğini, bilakis kamusal düzen ve devletin işleyişi bakımından da önemli bir husus olduğunu kabul ederek, mahkemelerin vicdani kanaatlerine göre karar verebileceğini, yargı 
bağımsızlığı bağlamında AY m.138/1'de ayrıca hükme bağlamıştır. AY m.138/1 düzenlemesi gereği mahkemenin mahkumiyet kararını suçluluğa ilişkin vicdani kanaate ulaşarak vermesi elzemdir. Aşağıda bu konu tekrar ele alınacağından, burada daha fazla ayrıntıya girmemeyi ve bu kısa açıklamayla yetinmeyi uygun buluyoruz.

\section{B. Alternatif Çözüm Yolunun İsnat Altındaki Kimsenin Adil Yargılanma} Hakkını İhlal Etmemiş Kabul Edilmesi İçin Aranan Koşullar

Alternatif çözüm yollarıyla, isnat hakkındaki kimseler hakkında yargılama yapılıp mahkumiyet hükmü verilebilmesi, AİHM tarafından doğrudan AİHS'ye aykırı kabul edilmemektedir. Nitekim şüpheli veya sanık bakımından, ceza indirimi gibi, ciddi birtakım avantajlar barındıran bu tür kurumlar, aynı zamanda yargılamaların hızlandırılması ve mahkemelerin iş yükünün azaltılmasına da hizmet etmektedir. Ancak bu tür kurumlara ilişkin uygulamalarda hak ihlalin bulunmadığının kabul edilebilmesi için AİHM içtihatları ile ortaya konmuş bir takım önemli hususların varlığ zorunludur. Bu hususlar şu şekilde sıralanabilir;

Tam, Açık ve Anlaşılır Şekilde Bilgilendirme: Öncelikle seri muhakeme ve basit yargılama usulleri gibi alternatif çözüm yollarıyla hakkında hüküm kurulacak kişinin, kurumun kendisi bakımından ortaya çıkartacağı sonuçlar ve ne şekilde uygulanacağı konusunda tam, açık ve anlaşılır şekilde bilgilendirilmesi gerekir. Kural olarak şüpheli veya sanığa alternatif çözüm yollarının uygulanmasını kabul etmesi halinde, ceza indirimi gibi önemli avantajlar sağlanacaktır. Bununla birlikte bazı temel hakların sağladığı teminatlardan da somut olay bakımından feragat etmesi gerekir. İşte isnat altındaki kişinin kendisine sağlanan tüm bu avantajlar ve kullanmaktan feragat edeceği haklar bakımından yeterli ölçüde bilgilendirmenin yapılması gerekir. CMK'da seri muhakeme usulü bakımından bu hususların ayrıntılı şekilde güvenceye bağlandığı kanaatindeyiz.

İsnat Altındaki Kimsenin Kurumun Uygulanmasına Müdafi Huzurunda Rıza

Göstermesi: Söz konusu alternatif çözüm yolları bakımından bulunması aranan ikinci koşul, bilgilendirme sonrasında tam aydınlatılmış kimsenin, ilgili usulün uygulanmasına müdafi huzurunda rıza göstermesi gerekliliğine ilişkindir. Müdafiin şüpheli veya sanıktan aydınlatılmış onam alınırken hazır bulunması, hem onun kurum hakkında ayrıntılı olarak bilgilendirildiği hem de bu bilgilendirme karşısında açık rıza verdiğinin teminatını 
oluşturacaktır. Dolayısıyla isnat altındaki kişiden söz konusu usulünün uygulanmasına ilişkin müdafi huzurunda, tam aydınlatılmış bir onam alınmalıdır. CMK'da bu hususta da gerekli düzenlemelere yeteri kadar yer verildiği kanaatinde olduğumuzu ifade etmek isteriz.

\section{İlgili Alternatif Çözüm Yolunun Uygulanacă̆ Suç Tiplerinin Kamusal Menfaat} Bakımından Ciddi Derecede Önem Arz Etmemesi: Seri muhakeme gibi usullerin uygulanacağı suç tiplerinin kamusal menfaat bakımından göreli olarak büyük önem taşımaması elzemdir. Kamusal menfaatin ağır bastığı suç tipleri bakımından bu tür usullerin uygulanması, ilgili buna rıza gösterse bile kabul edilemez. CMK'da özellikle seri muhakemeye ilişkin düzenlemelerde bu hususta ciddi handikaplar bulunduğunu ifade etmek gerekir.

AİHM de seri muhakeme usulü vb. kurumlara ilişkin olarak, önüne gelen değişik davalarda, yukarıda belirttiğimiz koşullara riayet edilmesi durumunda, bir hukuk sisteminde söz konusu kurumlara uygulama alanı tanınmasının sözleşmeye aykırılık oluşmayacağı yönünde kararlar vermektedir. Mahkemeye göre, kural olarak AİHS'de yer alan adil yargılanmaya ilişkin alt haklardan isnat altında bulunan kimsenin rızasıyla vazgeçemeyeceğine dair bir hüküm sözleşmede yer almamaktadır. Dolayısıyla aydınlatılmış olarak rızası alınan kişiyle ilgili olarak, kamusal menfaat de aksini gerektirmiyorsa, seri muhakeme vb. kurumlarla hüküm kurulması adil yargılanma hakkının ihlalini oluşturmayacaktır. Bu bağlamda AİHS'nin 6. maddesinin ne ruhu ne de lafzı kişinin adil yargılanmanın belli güvencelerinden, kendi isteğiyle, açıkça veya zımnen vazgeçmesini engellemektedir. Ancak, bir haktan vazgeçmenin AİHS bakımından etkin olması için kişinin bu haktan vazgeçtiği net bir şekilde tespit edilmeli ve bu haktan vazgeçmesine mütenasip asgari güvenceler sağlanmalıdır. Ayrıca, bu durum herhangi önemli bir kamu menfaatine aykırı olmamalıdır ${ }^{84}$.

84 Bkz. Hermi/Ittalya, B.N.: 18114/02, K.T.: 18.10.2006, p. 73. http://hudoc.echr.coe.int/tur?i=001-77543 (erişim tarihi 08.10.2020); Sejdovic/İtalya, B.N: 56581/00, K.T.: $01.03 .2006, \quad$ p. 86. http://hudoc.echr.coe.int/tur?i=001-72629 (erişim tarihi 08.10.2020). Ayrıca bkz. Avrupa KonseyiAvrupa İnsan Hakları Mahkemesi Ortak Yayını, 6. Madde Rehberi-Adil Yargılanma Hakkı (Ceza Hukuku Yönü), Ankara, 2014, s.39 
Örneğin AİHM, Hermi/Italya kararında, seri muhakeme usulüne ilişkin esasları değerlendirmiştir ${ }^{85}$. Buna göre; seri muhakeme incelemesinin açık olarak yapılmaması başvuranın kendi rızasıyla talep ettiği basitleştirilmiş bir usul olan seri muhakeme usulünün benimsenmesinin içeriğinde yer almaktadır. Dolayısıyla başvuran, bunu bilerek usulün uygulanmasını kabul etmiştir. Seri muhakeme usulünün davalı için şüphesiz avantajları vardır. Bu bağlamda isnat altındaki kimse hüküm giydiği takdirde, büyük oranda azaltılmış ceza almaktadır. Ayrıca isnat altındaki kişinin rıza gösterdiği hüküm için karşı tarafın başvurabileceği etkili bir kanun yolu da yoktur. Öte yandan, seri muhakeme usulü, iç hukuk tarafından sağlanan dava usulüne ait garantilerin azalmasına neden olmaktadır. Kendisinin seçmiş olduğu iki avukat tarafından savunulan başvuranın, seri muhakeme usulünün uygulanması talebinin sonuçlarının şüphesiz olarak farkındadır. Ayrıca, yukarıda bu usulün uygulanmasının kamu menfaatiyle ilgili herhangi bir soru ortaya çıkarmadığı görülmektedir. Seri muhakeme usulünde açık duruşma yapılmasının gerekli olup olmadığının belirlenirken ise, davanın makul bir süre içerisinde görülmesi hakkı ve mahkemelerin dosyaları süratli bir şekilde inceleme zorunluluğu dahil olmak üzere diğer hususların da dikkate alınması gerekir. İtalyan yasama organı, seri muhakeme usulünü uygulamaya başlayarak, cezai kovuşturmasını basitleştirmeyi, dolayısıyla hızlandırmayı amaçlamış görünmektedir. Bu bağlamda ilk ve ikinci derece mahkemeleri tarafından yapılan duruşmaların özel ve dolayısıyla dinleyiciler olmaksızın gerçekleşmesi, AİHS'nin bir ihlâli olarak algılanamaz.

Mahkeme özellikle yargılamaların hakimin tarafsızlığg ve duruşmaların aleniyeti başta olmak üzere, adil yargılanma hakkı kapsamındaki birçok haktan sanığın feragat edebileceğine dair başkaca kararlar da vermiştir. Örneğin; isnat altındaki kişi hakimin tarafsızlığına ilişkin haktan, belirli koşullar altında, feragat etmişse adil yargılanma hakkının ihlal edilmediği kabul edilmektedir. Ancak mahkeme feragat dolayısıyla adil yargılanma hakkının ihlalinin söz konusu olmadığına karar verdiği hallerde, feragatın

85 Kararın değerlendirmesi için bkz. CENGİZ, Serkan / DEMİAĞ, Fahrettin / ERGÜL, Teoman, vd., , Avrupa İnsan Hakları Mahkemesi Kararları Işı̆̆ında Ceza Yargılaması Kurum ve Kavramları, Türkiye Barolar Birliği ve Avrupa Konseyi Yayını, Şen Matbaa, Ankara, 2008, s.125 vd. 
şüpheye yer vermeyecek biçimde yapılmış olmasını aramaktadır ${ }^{86}$. Benzer şekilde AİHM, aleniyetten de feragat edilmesini kabul etmektedir. Hatta kamu yarına aykırı olmadıkça, bu feragatın açık veya zımni olmasının da önemi bulunmamaktadır ${ }^{87}$. Feragatın zımni olduğu hallerde bunun tereddüde yer vermeyecek şekilde olması ve kamu menfaatiyle ters düşmemesi gereklidir ${ }^{88}$. Eğer başvurucunun talep etmesi halinde duruşma yapılacağı iç hukukta düzenlenmişse, kamu menfaatiyle çatışmadığı müddetçe, sanığın duruşma talep etmemiş olması zımni feragat olarak nitelendirilir ${ }^{89}$. Hakansson ve Sturesson/İsveç davasında ise mahkeme, özellikle ceza davalarında sanığın kapalı duruşma talep etmesi halinde, mahkemenin sanığın menfaati ile kamu menfaati arasında bir orantı kurmak suretiyle talebi reddetmesini haklı bulmuştur. AİHM'ye göre aleniyetten feragat etmenin kamu yararına önemli derecede aykırı olduğu hallerde, aleniyetin sağlanması zorunludur ${ }^{90}$.

Yukarıdaki mahkeme kararlarından da açıkça anlaşıldığı üzere, AİHM, isnat altındaki kimsenin adil yargılanma hakkı kapsamındaki güvencelerden müdafi huzurunda feragat ettiği hallerde dahi uyuşmazlığın kamusal menfaat bakımından ciddi önem arz edip arz etmediğini denetlemektedir. Bu bağlamda kamusal menfaat bakımından ciddi öneme haiz davalarda, isnat altındaki kişi müdafi huzurunda haklarından feragat etmiş bile olsa bu durum adil yargılanma hakkının ihlalini oluşturacaktır. Nitekim bu hak, sadece bireysel menfaatleri değil; kamusal menfaatleri de koruma altına almaktadır. Uyuşmazlığın kamusal bakımdan ciddi bir önemi olup olmadığg belirlenirken göz önünde

86 D./İrlanda davasında, başvurucunun Sunday gazetesine karşı açtı̆̆ı davanın temyiz incelemesini yapan hakimlerden birisi, gazetenin birkaç hissesine sahiptir. Başvurucu bu konuda mahkeme kalemi tarafından bilgilendirildiği halde ne duruşma öncesinde ne de duruşma sırasında itiraz etmemiştir. Komisyon kendisine imkan verildiği halde başvurucunun tarafsızlığa ilişkin herhangi bir itirazda bulunmaması nedeniyle AİHS m.6/1'in ihlal edilmediği sonucuna ulaşmıştır. D./İrlanda, B.N.: 26499/02, K.T: 27.06.2006 http://hudoc.echr.coe.int/tur?i=001-76233 (erişim tarihi 08.10.2020).

87 LADEWİG, Hans-Meyer, “Adil Yargılanma Hakkı-II”, Adil Yargılanma Hakkı ve Ceza Hukuku, (çev. H. Hakeri), Seçkin Yayınevi, Ankara, 2004, s.89

88 Hakansson ve Sturreson/İsveç, B.N.: 11855/85 K.T.: 21.02.1990 http://hudoc.echr.coe.int/tur?i=001$\underline{57638}$ (erişim tarihi 08.10.2020). Werner/Avusturya; B.N.: 21835/93 K.T.: 24.11 .1997 http://hudoc.echr.coe.int/tur?i=001-58114 (erişim tarihi 08.10.2020).

89 Zumtobel/Avusturya; B.N: 12235/86 K.T.: 21.09.1993, p. 33-34 http://hudoc.echr.coe.int/tur?i=001$\underline{57847}$ (erişim tarihi 08.10.2020).

90 Hakansson ve Sturesson/İsveç, p. 44-50. 
bulundurulacak en önemli husus, uyuşmazlık konusu fiilin ilişkin olduğu suçun ağırlığıdır. Bu bağlamda isnat altındaki kişi bakımından ağır yaptırımlar öngören suçlara ilişkin uyuşmazlıklarda seri muhakeme usulünün kabulü hak ihlali oluşturacaktır. Dolayısıyla kasten öldürme, uyuşturucu ve uyarıcı madde imal ve ticareti gibi ağır nitelikteki suçlar seri muhakeme usulü kapsamına alınamaz.

\section{SERİ MUHAKEME USULÜNE İLISSKİN DÜZENLEMELERDE, ADİL YARGILANMA HAKKI VE DİĞER BAZI ANAYASAL ÍLKELER BAKIMINDAN TESPIT EDILEN SORUNLAR}

AİHM alternatif çözüm yollarına ilişkin uygulamaları doğrudan AİHS'nin ihlali olarak kabul etmemektedir. Ancak özellikle adil yargılanma hakkı bakımından ihlal olmadığının kabulü için birtakım koşulların gerçekleşmesi gereklidir. Bu hususa ilişkin açıklamaları bir önceki başlıkta ayrıntılı olarak yapmıştık. Bu nedenle, burada bu hususu vurgulamakla yetinmeyi uygun buluyoruz.

Bununla birlikte AİHM'nin kabul ettiği koşulları 7188 sayılı Kanun'la hukuk sistemimize giren seri muhakemeye ilişkin hükümlerin ne oranda karşıladığının da tespiti gereklidir. Bunun yanında anayasamızda yer alan hükümler bağlamında, AİHS hükümlerine aykırılığı bulunmayan alternatif çözüm yollarına ilişkin kanuni bir düzenlemenin, aykırılığının söz konusu olması da mümkündür. Daha önce de belirttiğimiz üzere, anayasanın temel hak ve özgürlükler arasında düzenlediği haklar bakımından, AİHM gibi bir hareket tarzı benimsenerek, belirli koşulların varlığı durumunda, isnat altındaki kişinin rızasıyla, somut olayda muhakemeye ilişkin temel hakları kullanmaktan vazgeçebileceğinin kabulü gerekir. Ancak ilgili hak bakımından anayasanın başka bölümlerinde de düzenleme getirilmişse; bir başka deyişle, anayasa koyucu söz konusu kişisel teminata, devletin yapısı ve kamusal düzen bakımından ayrıca bir önem atfetmişse, bu halde temel hakka yapılacak söz konusu müdahale anayasaya aykırı olacaktır. Nitekim anayasa koyucu AİHS'den farklı olarak, bazı uygulamaları kamusal menfaat bakımından sakıncalı görmüştür.

Seri muhakeme usulü gerek Anayasa m.36 gerekse de AİHS m.6' da hüküm altına alınmış olan adil yargılanma hakkı bağlamında ciddi handikaplar barındırmaktadır. 
Özellikle aleni duruşmada yargılanma hakkı, rızasıyla da olsa sanığın elinden alınmaktadır. Yukarıda da ifade ettiğimiz üzere; AİHM, birtakım koşullar altında seri muhakeme gibi alternatif çözüm yollarına ilişkin uygulamaların adil yargılanma hakkını ihlal etmediğini kabul etmektedir. AİHM bakımından içtihatlarla ortaya konulan koşullar iç hukukumuzdaki düzenlemelerde büyük oranda karşılanmıştır. Ancak kamusal öneme haiz suç tiplerinde seri muhakeme tarzı uygulamalara yer verilemeyeceği şeklindeki kıstas bakımından önemli sorunlar bulunmaktadır. Bunun yanında AİHM tarafından adil yargılanma hakkı ihlali olarak görülmese bile, anayasal düzenlemelerden kaynaklı olarak başkaca anayasal ilkelere aykırılık oluşturan hususlar da bulunmaktadır. Aşağıda bu hususları numaralandırarak ayrı ayrı ele almayı uygun buluyoruz.

1) Öncelikle belirtmek gerekir ki; CMK m. 250 ile hükme bağlanan seri muhakeme kapsamındaki suçlar arasında, oldukça ağır yaptırım içeren suçlar bulunmaktadır. Bu bağlamda söz konusu suçlarla ilgili olarak, özellikle ağır cezaların ortaya çıkabileceği hallerde seri muhakeme usulünün uygulanması, kamusal menfaate ciddi anlamda zarar verecek, bu durum ise hem adil yargılanma hakkı bağlamında AİHS'ye hem de Anayasa'ya aykırılık teşkil edecektir. Genellikle seri muhakeme usulüne tabi suçların ispatı kolay ve ağır nitelikte olmayan suçlar olduğu ileri sürülmektedir. Oysa bu suçların ispatının her zaman kolay ve net olduğunu söylemenin yanlışlı̆̆ı bir tarafa bırakılsa dahi; söz konusu suçların tamamının ağır nitelikte olmadığını söylemek zordur ${ }^{91}$. Örneğin seri muhakeme usulü kapsamında yer alan parada sahtecilik suçu (TCK m.197), iki yıldan on iki yıla kadar hapis ve on bin güne kadar adlî para cezasını gerektirmektedir. Bunun yanında TCK m. 268'de düzenlenen başkasına ait kimlik bilgilerinin kullanılması suçunun cezası bakımından TCK m. 267'de düzenlenen iftira suçuna ilişkin hükümlere atıf yapılmıştır. TCK m.267'de düzenlenen iftira suçu ise TCK m.61/1'in uygulanması kapsamında doğrudan alt ve üst sınırı dikkate alınacaktır. Ancak TCK m. 267 suçun temel şeklinden bağımsız yüksek ceza içeren birçok netice

91 "Bu suçlar önemsiz görüldü̆ğ̈ takdirde cezaları indirilmelidir. Önemsiz değilse doğrudan doğruyalık, sözlülük, alenilik ilkelerinden vazgeçilmemeli, sanıkların tanıklara soru sorma hakkı ellerinden alınmamalıdır." Bkz. CENTEL / ZAFER, 2020, s. 621. "Basit yargilama kapsamina iki yıla kadar hapis cezasinı gerektiren suçlar girmektedir. Savcının yetkisinde olan seri muhakeme usulünde cezast daha ağır olan bazı suçların kapsama alınması orantısız bir düzenleme olmuştur.” Bkz. CENTEL / ZAFER, 2020, s. 1019. 
sebebiyle ağırlaşmış hal barındırmaktadır. Örneğin, hakkında soruşturma ve kovuşturma yapılmasını engellemek ve suçu kimlik bilgilerini kullandığı mağdurun üzerine atmak için bu kişiye ait kimlik bilgilerini kullanan kimsenin fiili sonucunda, mağdur müebbet veya ağırlaştırılmış müebbet hapis cezasına mahkum olursa, faile 20 yıldan 30 yıla kadar hapis cezası verilecektir (Bkz. TCK m. 268 göndermesiyle TCK m.267/5). Adli Teşkilat Kanunu m.12 gereğince ağır ceza mahkemesinin görev alanına giren bu nitelikte bir fiilin kamusal menfaat bakımından fazla önem arz etmediğini söylemek mümkün görünmemektedir.

2) Bunun yanında kişinin bağımsız bir mahkeme önünde yargılanma hakkı vardır. Anayasa m.9' da da yargı yetkisinin bağımsız ve tarafsız mahkemelerce kullanılacağı hükme bağlanmıştır. Anayasa m. 138' de ise hakimlerin anayasaya, kanuna ve hukuka uygun olarak vicdani kanaatlerine göre hüküm verecekleri düzenlenmiştir. Oysa seri muhakemede mahkeme, vicdani kanaatine göre karar vermemektedir. Bilakis işin esasını, yani maddi gerçeği araştırma yetkisi bulunmamaktadır. Seri muhakeme usulü kanuna uygun şekilde uygulandıysa, talepnamedeki yaptırım doğrultusunda hüküm kurmaktadır $^{92}$. Ayrıca gerek AİHS m.6/2 gerekse de Anayasa m.38/4 gereğince, isnat altındaki kişilerin suçsuzluk karinesinden faydalanması esastır. Buna göre; "suçluluğu hükmen sabit oluncaya kadar kimse suçlu sayılamaz (AY m.38/4).” Bu ilkenin önemli sonuçlarından biri de "şüpheden sanı̆̆ın yararlanması"dır. Çünkü isnat altındaki kişi mahkeme tarafından vicdani kanaate ulaşılıp mahkumiyet kararı verilinceye (suçluluğu hükmen sabit oluncaya) kadar suçlu sayılamaz. Bu nedenle genel muhakeme usulünde, mahkemenin mahkumiyet kararı verebilmesi için vicdani kanaate ulaşması zorunlu iken (CMK m.223/5), beraat kararı suçsuzluğa ilişkin vicdani kanaate ulaşıldığında verilebileceği gibi (CMK m.223/2/b), sanığın suçluluğunun şüpheli kaldığı durumlarda da (CMK m.223/2/e) verilebilmektedir. Oysa seri muhakemede savcının bu usulü başlatması için şüphelinin suçu işlediğine dair yeterli şüphe bulunması yeterlidir. Bunun üzerine şüpheli usulün uygulanmasını kabul ederse ve süreç hukuka uygun ilerlerse, mahkemenin yeterli şüphe üzerine mahkumiyet hükmü vermesi söz konusu olacaktır. Bu

92 Benzer eleștiriler için bkz. BAYTAZ, 2020, s. 8 vd., UĞURLUBAY / HAYDAR / KORKMAZ, 2019, s. 288; TAŞKIN, 2020, s. 51. 
da suçsuzluk karinesini ciddi şekilde zedeleyen bir durumdur ${ }^{93}$. Bu noktada hakkında yeterli şüphe bulunan şüphelinin seri muhakeme usulünün uygulanmasını kabul etmesinin bir tür ikrar sayılıp, bu ikrarın da yeterli şüphe derecesini suçluluğa ilişkin vicdani kanaat derecesine taşıdığının kabul edilip edilemeyeceği hususu akla gelebilir. Bu ihtimali birkaç nedenle olumlamak mümkün değildir. Öncelikle böyle bir usulün uygulanmasına rıza gösterilmesi ikrar sayılamaz. Şüpheli yargıya güvensizlik, haklı da olsa daha fazla ceza ile cezalandırılma korkusu, daha ağır yaptırımlara yönelik risk almama eğilimi gibi nedenlerle seri muhakeme usulünün uygulanmasını kabul etmiş olabilir. Dolayısıyla usulün uygulanmasının kabulü, ikrar gibi değerlendirilemez ${ }^{94}$. Ayrıca bir an için ikrar olarak değerlendirilebileceği kabul edilse bile, ceza muhakemesinde ikrar otomatikman vicdani kanaati tesis etmez. Kişi değişik gerekçelerle işlemediği suçu işlemiş gibi ikrarda bulunabilir. Bu nedenle ikrar halinde bile mahkemenin beraata karar verme imkanı vardır. Bu gibi durumların yaşanabileceğini öngören kanun koyucu da TCK m.270’te suç üstlenme adlı bir suç tipine yer vermiştir.

Bu noktada isnat altındaki kişinin belirli koşullar altında, hakkında seri muhakeme usulünün uygulanmasını kabul etmesine imkan tanınmasının, AİHM içtihatlarındaki mantıkla, Anayasa'ya aykırı kabul edilemeyeceği, bu nedenle kişinin suçsuzluk karinesinden faydalanmaktan vazgeçebileceği ileri sürülebilir. Kanaatimizce de Anayasa'nın temel hak ve özgürlükler arasında düzenlediği haklar bakımından, AİHM'nin kullandığı mantıkla, yukarıda açıkladığımız koşulların varlığı durumunda, kişinin kendisine tanınan avantajları göz önünde bulundurarak, rızasıyla, somut olayda muhakemeye ilişkin temel hakları kullanmaktan vazgeçebileceğinin kabulü gerekir.

93 Aynı yönde bkz. UĞURLUBAY / HAYDAR / KORKMAZ, 2019, s. 298; YENISEY / NUHOĞLU, 2020, s. 847.

94 Aynı yönde bkz. BAYTAZ, 2020, s. 18, "Serî muhakeme usûlünü düzenleyen hükümlerden şüphelinin suçluluğundan yola çıklldı̆̆ gözlenmektedir. Cumhuriyet savcısı her ne kadar başlangıç şüphesi olmadan soruşturma evresine başlayamayacak olsa da, serî muhakeme usûlünü sürdürmek ve talepnâme hazırlamak için herhangi bir özel şüphe derecesi aranmamışsır ki-yukarıda da anıldı̆̆ üzere talepnâme iddianâmeden öte bir anlam taşımaktadır. Bunun yanında şüphelinin usûlün uygulanmast teklifini kabul etmesinden sonra herhangi bir delil sunma ve savunma ya da delil değerlendirme sürecinden söz edilmemektedir. Üstelik öyle anlaşllmaktadır ki prosedür, şüphelinin ikrârt ile başlamaktadır. Dolaylsiyla aslında tüm adlî makamlar tarafindan riayet edilmesi gerekilen masûmiyet karinesine Cumhuriyet savcisinca uyulmamaktadır." Bkz. UĞURLUBAY / HAYDAR / KORKMAZ, 2019, s. 287. 
Ancak ilgili temel hak bakımından, temel hak ve özgürlükler dışında, Anayasa'nın başka bölümlerinde de düzenleme getirilmişse, bir başka deyişle, anayasa koyucu söz konusu kişisel teminata, devletin işleyişi ve kamusal düzen bakımından ayrıca bir önem atfetmişse; bu halde söz konusu hakka yapılacak müdahalenin, Anayasa'ya aykırı olduğunun kabulü gerekir. Bu bağlamda şüpheden sanığın yararlanması, Anayasa m.38'de hükme bağlanmış temel haklardandır. Ancak anayasa koyucu, bu teminatın sadece bireyler bakımından önem arz etmediğini, kamusal düzen ve devletin işleyişi bakımından da önemli bir husus olduğunu kabul ederek, mahkemelerin vicdani kanaatlerine göre karar verebileceğini, yargı bağımsızlığı bağlamında AY m.138/1'de ayrıca hükme bağlamıştır. AY m.138/1 düzenlemesi gereği mahkemenin mahkumiyet kararını suçluluğa ilişkin vicdani kanaate ulaşarak vermesi elzemdir. Bu bağlamda anayasa koyucunun bakış açısıyla düşünüldüğünde; seri muhakeme usulünde, mahkemenin savcının talepnamesi ile bağlı tutulması, sadece bireysel haklar bakımından değil; aynı zamanda devletin sağlıklı işleyişi ve bakımından da ciddi bir tehlike arz etmektedir. Kaldı ki; hukukumuzda şu ana kadar seri muhakeme dışında herhangi bir kurum, mahkemenin vicdani kanaati dışında mahkumiyet kararı verebilmesine imkan tanımamıştır ${ }^{95}$. Bu noktada akla önödeme vb. kurumlar gelebilir. Ancak bu kurumların uygulanması neticesinde kişi belirli bir miktar adli para cezası ödese de bu durum onun hakkında mahkumiyet hükmünün sonuçlarını doğurmamaktadır. Bu bağlamda, hukuken bir mahkumiyet hükmü var olmamakta, dolayısıyla tekerrüre esas olma, adli sicile işleme veya memuriyete engel olma gibi sonuçlar ortaya çıkmamaktadır. Ancak seri muhakemede, cezada indirim yapılsa da mahkumiyet hükmü tüm sonuçları ile ortaya çıkmakta ve kişiye hapis cezası verilebilmektedir.

Bunun yanında aleni yargılanma hakkının anayasa m.141'de hükme bağlandığı, bu nedenle adil yargilanma hakkı (AY m.36; AİHS m.6/1) kapsamında yer alan bu alt hakkın da kamusal düzen bakımından önem arz ettiği ve istisnasının olamayacağı düşünülebilir. Ancak AY m.141'de duruşmaların aleni olduğu hüküm altına alınmıştır. Duruşmasız

95 Benzer yönde; "Serî muhakeme usûlünün anayasal açıdan en sorunlu olduğu yerlerden biri kanunî hâkim ilkesi ile tarafsız ve bağımsız mahkeme tarafindan yargılanma ilkesi bağlamındadır. Yenilenecek normda yargılama yetkisinin savcıdan alınarak, istisnâsı bir şekilde hâkime aktarılması zorunludur." Bkz. UĞURLUBAY / HAYDAR / KORKMAZ, 2019, s. 301. 
yargılamaya cevap verilmemesi diye bir şey söz konusu değildir. Yargılamalar duruşmalı yapılıyorsa aleniyet zorunludur. Ancak yapısı gereği duruşma öngörülmemiş hukuki uyuşmazlıklar bakımından, aleniyetin klasik anlamdaki açıklık olarak sağlanması zorunlu değildir. Bu bağlamda seri muhakemenin aleni olmaması kanaatimizce ne anayasaya ne de AİHS'ye aykırıdır.

3) Son olarak belirtmek gerekir ki; daha önceki yüksek mahkeme içtihatları dikkate alındığında, seri muhakeme usulü de tıpkı basit yargılama usulü gibi çifte karakterli bir kurumdur. Bunun yanında basit yargılama usulünün uygulanmasında mahkemenin takdir hakkı varken, seri muhakeme usulünün koşulları oluştuğunda uygulanması zorunludur. $\mathrm{Bu}$ bağlamda seri muhakeme usulünün uygulanması, bu kapsamdaki uyuşmazlıklar bakımından muhakeme şartı oluşturmaktadır. Anayasa Mahkemesi daha önceki Yargıtay içtihatlarıyla da uyumlu şekilde, basit yargılama usulünün uygulanmaya başlanacağı zamana ilişkin bir uygulama hükmünün, belirli kısmının iptaline karar vermiştir. Nitekim Yargıtay yıllardır yerleşik uygulamasında, temelde ceza muhakemesi kurumu olmakla birlikte, yargılamanın yapılmasına ve cezanın miktarına dolaylı da olsa etkisi olan hukuki kurumları, çifte karakterli (hem maddi ceza hukuku hem de ceza muhakemesi hukuku niteliği olan) kurumlar olarak kabul etmektedir. Buna bağlı olarak (şikayet, izin, HAGB gibi) bu tür kurumlara ilişkin hükümlerin zaman bakımından uygulanmasında ise lehe kanun uygulaması yapılacağına hükmetmektedir ${ }^{96}$. CMK geçici m. 5/1/d'de şu hükme

96 "Kamu görevlisine karşı görevinden dolayı işlenmesi hariç hakaret suçlarının soruşturulması ve kovuşturulmast şikayete bağlıdır. Mağdurun şikayetçi olması halinde yeni Türk Ceza Kanunu ve Ceza Muhakemesi Kanunu uyarınca uzlaşma işlemi yapllp sonuca göre karar verilmelidir. Somut olayda, anılan yasalar hüküm tarihinden sonra yürürlüğe girmiștir. Açılanan nedenlerle sanığın hukuki durumunun yeniden değerlendirilmesi gerekir." Yar. 2. CD., 06.02.2006, E. 2005/2619, K. 2006/1356. "5237 sayll TCK'nın 125. maddesinde düzenlenen ve sanığın eylemine uyan hakaret suçunun, 131/1. maddesinde düzenlenen kamu görevlisine karşı görevinden dolayı işlenmesi hali hariç olmak üzere, soruşturulması ve kovuşturulmasının şikayete bağlı olması ve mağdurun şikayetçi olması karşısında, 5271 sayıl CMK'nın 253 ve 254. maddeleri uyarınca uzlaştırma işlemi yapılmall, sonucuna göre karar verilmelidir." Yar. 2. CD.,27.02.2006, E. 2005/4591, K. 2006/3340. "Öncelikle lehe olduğundan kuşku bulunmayan ve diğer kişiselleştirme nedenlerinden önce Yargı̧ tarafindan isteme bağlı olmaksızın değerlendirilmesi zorunluluğu bulunan hükmün açılklanmasının geri bırakılması koşullarının bulunup bulunmadlğı değerlendirilerek sanığın hukuki durumunun saptanmasinda zorunluluk bulunmaktadır." Yar. CGK., 03.06.2008, E. 2008/2-149, K. 2008/163. "Sanığın zincirleme biçimde görevli memura sövme suçundan cezalandırlmasina ilişkin hükmün verilmesinden sonra yürürlüğe giren 5728 sayll Yasanin 562. maddesi ile Ceza Yargllamasi Yasasi'nın 231. maddesinin 5 ve 14. fikralarinda gerçekleştirilen değiş̧iklikler sonucunda, bu maddede öngörülen objektif ve subjektif koşulların varlı̆ğ halinde uygulanması olanağı bulunan `hükmün açıklanmasının geri bırakılması` kurumunun tatbik 
yer verilmiştir; "1/1/2020 tarihi itibarlyla kovuşturma evresine geçilmiş, hükme bağlanmış veya kesinleşmiş dosyalarda seri muhakeme usulü ile basit yargılama usulü uygulanmaz." Lehe kanun uygulaması gereği, basit yargılama usulünün uygulanması sanık bakımından cezada indirim sağladığı için CMK m.251 vd. yürürlüğe girdikten sonra, kapsamında yer alan ve kesin hükme bağlanmamış tüm uyuşmazlıklar bakımından etkili olmalıdır (Bkz. TCK m.7/2) ${ }^{97}$. Bu nedenle, kendisine yapılan bir başvuru kapsamında Anayasa Mahkemesi, CMK geçici m.5/1/d hükmünün basit yargılamaya ilişkin belirli bir kısmının iptaline karar vermiştir. ${ }^{98}$ Ancak burada vurgulamak gerekir ki; iptal kararının gerekçesinde belirtilen hususlardan daha fazlası seri muhakeme usulü için de geçerlidir. Bu nedenle söz konusu hükmün seri muhakemeye ilişkin kısmının da iptali gerekir. $\mathrm{Bu}$ noktada soruşturmaya ilişkin bir kuruma kovuşturmaya geçtikten sonra uygulama alanı tanınmasının, "muhakeme evrelerinden geri dönüş olmaz" ilkesine aykırılık oluşturacağı hususu akla gelebilir. Ancak daha önceki başlıklarda ayrıntılı olarak açıkladığımız üzere, bu şekildeki hareket tarzı, bir tür evrelerden geri dönüş değil; bilakis bir muhakeme şartının gerçekleştirilmesine yönelik faaliyet olarak kabul edilmeli, şart gerçekleşmezse muhakeme kaldığı yerden devam etmelidir. $\mathrm{Bu}$ bağlamda seri muhakemeye ilişkin yapılacak lehe kanun uygulaması bakımından da bir sakıncanın ortaya çıkmayacağı kanaatindeyiz.

alanı genişletilmiş ve somut olayda uygulanabilir bir hale gelmiştir. Kurulan hükmün sanık hakkında hukuki bir sonuç doğurmamasına olanak sağlayan ve bu yönüyle sanık lehine sonuç doğurduğunda kuşku bulunmayan bu hukuki kurumun sanık hakkında uygulanıp uygulanmayacağı ise öncelikle birinci derece yargllamasını yapan mahkemece ele alınıp değerlendirilmelidir. Bu itibarla, diğer yönlerinin bu aşamada incelenmesine gerek bulunmayan hükmün, öncelikle bu yasal değişikliğin değgerlendirilebilmesi için bozulmasına karar verilmelidir." Yar. CGK, 01.04.2008, E. 2007/4MD-219, K. 2008/66 (Kazancı İçtihat Bilgi Bankası).

97 “...ceza muhakemesi kanunlarının zaman bakımından uygulanması konusunda tutarlılıktan söz edilmesi zordur. Birçok yazar, muhakeme normlarının uygulanması konusunda derhal uygulanırlık ilkesini kabul etmekte, ancak muhakeme şartları gibi çeşitli muhakeme normları bakımından lehe normun geçmişe uygulanmasını ya da yürürlük ötesi uygulanmasını da savunabilmektedir. Aynı durum yargl organlarl için de geçerlidir. Bu noktada belki, kişi özgürlügünü ilgilendiren ve kişi özgürlügünü ilgilendirmeyen muhakeme kuralları bakımından bir ayrım yapılması düşünülebilir. Kişi özgürlüğünün sınırlandırılması sonucunu doğuracak ceza normları bakımından geçmişe uygulama yasağının etki doğurması peşinen kabul edilebilir. Hiç olmazsa bu şekilde, ceza muhakemesi normlarının derhal uygulanmast ilkesi bakımından öğreti ya da uygulama tarafindan kabul edilen istisnalar bir sisteme bağlanabilir. Diğer seçenek ise, derhal uygulanırlık bakımından geçerli hükümler dışında herhangi bir istisna kabul edilmemesi, yani ilkenin harfiyen uygulanmasıdır." Bkz. KATOĞLU, Tuğrul, Ceza Kanunlarının Zaman Yönünden Uygulanması, Seçkin Yayınevi, Ankara, 2008, s. 319.

98 AYM, 25.06.2020, E. 220/16 K. 2020/33, R.G. No: 31218; R.G. Tarihi: 19.8.2020. 


\section{SONUÇ}

Uyuşmazlığın niteliğine uygun olarak makul bir sürede yargılanmak sanık bakımından adil yargılanmanın en önemli gereklerindendir. Adaletin makul bir sürede sağlanması özellikle masum kimselerin yargılandığı durumlarda bir an önce itibarlarının iadesi edilmesini sağlar. Öte yandan adaletin sürate feda edilmemesi de gerekir. Bu nedenle salt muhakemeyi çabuklaştırmak amacıyla adil yargılanmaya ilişkin ilkelerden vazgeçilemez. Adil yargılanma ve makul sürede yargılanma ilkeleri arasında bir denge gözetilmelidir.

Ceza Muhakemesi Kanunu'nda (CMK), 2019 yılında yapılan değişikliklerle birlikte hukuk sistemimize giren alternatif cezai uyuşmazlık çözüm yöntemlerinden biri seri muhakeme usulüdür. Seri muhakeme usulü; savcı ile şüphelinin kanunda belirtilen usulle anlaşmaları esasına dayanan, kanunda tahdidi olarak sayılan suçlara ilişkin muhakemeleri çabuklaştırmayı ve böylelikle mahkemelerin iş yükünü azaltmayı amaçlayan özel bir muhakeme türüdür. Kanunkoyucu bu usulle, mahkemelerin iş yükünü azaltmayı ve adil yargılanma hakkı kapsamında yer alan alt haklardan olan makul sürede yargılanma hakkını bireyler bakımından teminat altına almayı amaçlamıştır. Nitekim seri muhakeme usulünün uygulanması suretiyle bazı uyuşmazlıklar bakımından ilk derece mahkemelerinin ve dolayısıyla kanun yolu mercilerinin iş yükü azaltılacaktır. Böylelikle söz konusu merciler ellerinde olan diğer davalara daha çok vakit ayırabilecek ve bunları da daha kısa sürede adil biçimde çözüme kavuşturabileceklerdir.

Kanuni düzenleme dikkate alındığında, seri muhakeme usulüne başvurulmasının bir takım temel koşulları olduğu görülmektedir. Bunun yanında CMK ve ceza muhakemesine ilişkin hükümlerin yer aldığı diğer kanunlarda bulunan düzenlemelerden de bu koşullara ilişkin bazı sonuçlar çıkartılabilmektedir. Bu iki husus birlikte değerlendirildiğinde, seri muhakeme usulüne başvurulmasının temel koşulları şu şekilde siralanabilir;

1) Muhakeme konusu fiilin oluşturduğu suçun seri muhakeme usulüne tabi olmasi,

2) Yeterli şüpheye ulaşılmış olması, 
3) Kamu davasının açılmasının ertelenmesi kararı verilmemiş olması,

4) Şüpheliye ulaşılmış olması,

5) İştirak halinde işlenen suçlarda tüm fail ve şeriklerin seri muhakeme usulünün uygulanmasını kabul etmesi,

6) Muhakeme şartının gerçekleşmiş olması,

7) Şüphelide yaş küçüklüğü ve akıl hastalığı ile sağır ve dilsizlik hallerinden birinin bulunmamas1.

Anayasanın 36. maddesinde açıkça teminat altına alınan adil yargılanma hakkı, birçok yazar tarafından, Anayasanın 2. maddesinde hükme bağlanan hukuk devleti ilkesinin de bir gereği olarak kabul edilmektedir. Söz konusu hak 1948 tarihli İnsan Hakları Evrensel Bildirgesinin 10. maddesinde hükme bağlandığg gibi, Türkiye'nin taraf olduğu temel hak ve özgürlüklere ilişkin uluslararası sözleşmelerden olan Avrupa İnsan Hakları Sözleşmesi'nin (AİHS) 6. maddesinde, Birleşmiş Milletler Medeni ve Siyasal Haklar Sözleşmesi' nin ise 14. maddesinde bireyler bakımından teminat altına alınmıştır. Bunun dışında cezai uyuşmazlıklara ilişkin olarak, CMK'da da adil yargılanma hakkına ilişkin birçok husus hükme bağlanmıştır.

AİHS m.6 ışığında adil yargılanma; bireyin, gerek medeni hak ve yükümlülüklerine gerekse cezai alanda kendisine yöneltilen suçlamalara ilişkin herhangi bir davanın, yasayla kurulmuş, bağımsız ve tarafsı bir mahkeme tarafindan, makul bir süre içerisinde, aleni ve hakkaniyete uygun olarak görülmesine ilişkin hakkı olarak tanımlanabilir.

AİHM basit yargılama gibi alternatif çözüm yöntemleri ile isnat altındaki kimseler hakkında mahkumiyet hükmü kurulabilmesini AİHS'nin ve özellikle 6. maddede düzenlenen adil yargılanma hakkının bir ihlali olarak görmemektedir. Ancak bunun için birtakım koşulların gerçekleşmesini aramaktadır. Aksi takdirde ilgililerin adil yargılanma hakkı ihlal edilmiş olacaktır. Bu koşullar şu şekilde sıralanabilir;

*Tam, Açık ve Anlaşılır Şekilde Bilgilendirme 
*İsnat Altındaki Kimsenin Kurumun Uygulanmasına Müdafi Huzurunda Rıza Göstermesi

*İlgili Alternatif Çözüm Yolunun Uygulanacă̆ı Suç Tiplerinin Kamusal Menfaat Bakımından Ciddi Derecede Önem Arz Etmemesi

Bununla bağlamda AİHM'nin kabul ettiği koşulları 7188 sayılı Kanun'la hukuk sistemimize giren seri muhakemeye ilişkin hükümlerin ne oranda karşıladığının da tespiti gereklidir. Bunun yanında anayasamızda yer alan hükümler bağlamında, AİHS hükümlerine aykırılığı bulunmayan alternatif çözüm yollarına ilişkin kanuni bir düzenlemenin, anayasaya aykırılığının söz konusu olması da mümkündür. Anayasanın temel hak ve özgürlükler arasında düzenlediği haklar bakımından, AİHM gibi bir hareket tarzı benimsenerek, belirli koşulların varlığı durumunda, isnat altındaki kişinin rızasıyla, somut olayda muhakemeye ilişkin temel hakları kullanmaktan vazgeçebileceğinin kabulü gerekir. Ancak ilgili hak bakımından anayasanın başka bölümlerinde de düzenleme getirilmişse; bir başka deyişle, anayasa koyucu söz konusu kişisel teminata, devletin yapısı ve kamusal düzen bakımından ayrıca bir önem atfetmişse, bu halde temel hakka yapılacak söz konusu müdahale anayasaya aykırı olacaktır. Nitekim bu durumda, anayasa koyucu, AİHS'den farklı olarak, bazı uygulamaları kamusal menfaat bakımından sakıncalı görmüştür.

Seri muhakeme usulüne ilişkin CMK m.250'de yer alan düzenlemeler, adil yargılanma hakkı bağlamında ciddi handikaplar barındırmaktadır. Bu sorunlar şu şekilde numaralandırılarak siralanabilir;

1) CMK m. 250 ile hükme bağlanan seri muhakeme kapsamındaki suçlar arasında, oldukça ağır yaptırım içeren suçlar bulunmaktadır. Bu bağlamda söz konusu suçlarla ilgili olarak, özellikle ağır cezaların ortaya çıkabileceği hallerde seri muhakeme usulünün uygulanması, kamusal menfaate ciddi anlamda zarar verecek, bu durum ise hem adil yargılanma hakkı bağlamında AİHS'ye hem de Anayasa'ya aykırılık teşkil edecektir. Genellikle seri muhakeme usulüne tabi suçların ispatı kolay ve ağır nitelikte olmayan suçlar olduğu ileri sürülmektedir. Oysa bu suçların ispatının her zaman kolay ve net olduğunu söylemenin yanlışlığı bir tarafa bırakılsa dahi; söz konusu suçların tamamının ağır nitelikte olmadığını söylemek zordur. Örneğin seri muhakeme usulü kapsamında yer 
alan parada sahtecilik suçu (TCK m.197), iki yıldan on iki yıla kadar hapis ve on bin güne kadar adlî para cezasını gerektirmektedir.

2) Ayrıca kişinin bağımsız bir mahkeme önünde yargılanma hakkı vardır. Anayasa m.9'da da yargı yetkisinin bağımsız ve tarafsız mahkemelerce kullanılacağı hükme bağlanmıştır. Anayasa m. 138'de ise hakimlerin anayasaya, kanuna ve hukuka uygun olarak vicdani kanaatlerine göre hüküm verecekleri düzenlenmiştir. Oysa seri muhakemede mahkeme, vicdani kanaatine göre karar vermemektedir. Bilakis işin esasını, yani maddi gerçeği araştırma yetkisi bulunmamaktadır. Seri muhakeme usulü kanuna uygun şekilde uygulandıysa, mahkeme, talepnamedeki yaptırım doğrultusunda hüküm kurmaktadır. Ayrıca gerek AİHS m.6/2 gerekse de Anayasa m.38/4 gereğince, isnat altındaki kişilerin suçsuzluk karinesinden faydalanması esastır. Buna göre; "suçluluğu hükmen sabit oluncaya kadar kimse suçlu sayılamaz (AY m.38/4).” Bu ilkenin önemli sonuçlarından biri de "şüpheden sanığın yararlanması"dır. Çünkü isnat altındaki kişi mahkeme tarafından vicdani kanaate ulaşılıp mahkumiyet kararı verilinceye (suçluluğu hükmen sabit oluncaya) kadar suçlu sayılamaz. Oysa seri muhakemede savcının bu usulü başlatması için şüphelinin suçu işlediğine dair yeterli şüphe bulunması yeterlidir. Bunun üzerine şüpheli usulün uygulanmasını kabul ederse ve süreç hukuka uygun ilerlerse, mahkemenin yeterli şüphe üzerine mahkumiyet hükmü vermesi söz konusu olacaktır. Bu da suçsuzluk karinesini ciddi şekilde zedeleyen bir durumdur. Bu noktada isnat altındaki kişinin belirli koşullar altında, hakkında seri muhakeme usulünün uygulanmasını kabul etmesine imkan tanınmasının, AİHM içtihatlarındaki mantıkla, Anayasa'ya aykırı kabul edilemeyeceği, bu nedenle kişinin suçsuzluk karinesinden faydalanmaktan vazgeçebileceği ileri sürülebilir. Kanaatimizce de Anayasa'nın temel hak ve özgürlükler arasında düzenlediği haklar bakımından, AİHM'nin kullandığı mantıkla, yukarıda açıkladığımız koşulların varlığı durumunda, kişinin kendisine tanınan avantajları göz önünde bulundurarak, rızasıyla, somut olayda muhakemeye ilişkin temel hakları kullanmaktan vazgeçebileceğinin kabulü gerekir. Ancak ilgili temel hak bakımından, temel hak ve özgürlükler dışında, Anayasa'nın başka bölümlerinde de düzenleme getirilmişse, bir başka deyişle, anayasa koyucu söz konusu kişisel teminata, devletin işleyişi ve kamusal düzen bakımından ayrıca bir önem atfetmişse; bu halde söz konusu hakka yapılacak müdahalenin, Anayasa'ya aykırı olduğunun kabulü gerekir. Bu 
bağlamda şüpheden sanı̆̆ın yararlanması, Anayasa m.38'de (suçsuzluk karinesi kapsamında) hükme bağlanmış temel haklardandır. Ancak anayasa koyucu, bu teminatın sadece bireyler bakımından önem arz etmediğini, kamusal düzen ve devletin işleyiş̧i bakımından da önemli bir husus olduğunu kabul ederek, mahkemelerin vicdani kanaatlerine göre karar verebileceğini, yargı bağımsızlığı bağlamında AY m.138/1'de ayrıca hükme bağlamıştır. AY m.138/1 düzenlemesi gereği mahkemenin mahkumiyet kararını suçluluğa ilişkin vicdani kanaate ulaşarak vermesi elzemdir. Bu bağlamda anayasa koyucunun bakış açısıyla düşünüldüğünde; seri muhakeme usulünde, mahkemenin savcının talepnamesi ile bağlı tutulması, sadece bireysel haklar bakımından değil; aynı zamanda devletin sağlıklı işleyişi ve bakımından da ciddi bir tehlike arz etmektedir. Kaldı ki; hukukumuzda şu ana kadar seri muhakeme dışında herhangi bir kurum, mahkemenin vicdani kanaati dışında mahkumiyet kararı verebilmesine imkan tanımamıştır.

3) Son olarak belirtmek gerekir ki; daha önceki yüksek mahkeme içtihatları dikkate alındığında, seri muhakeme usulü de tıpkı basit yargılama usulü gibi çifte karakterli bir kurumdur. Bunun yanında basit yargılama usulünün uygulanmasında mahkemenin takdir hakkı varken, seri muhakeme usulünün koşulları oluştuğunda uygulanması zorunludur. $\mathrm{Bu}$ bağlamda seri muhakeme usulünün uygulanması, bu kapsamdaki uyuşmazlıklar bakımından muhakeme şartı oluşturmaktadır. Anayasa Mahkemesi daha önceki Yargıtay içtihatlarıyla da uyumlu şekilde, basit yargılama usulünün uygulanmaya başlanacağı zamana ilişkin bir uygulama hükmünün, belirli kısmının iptaline karar vermiştir. Nitekim Yargıtay yıllardır yerleşik uygulamasında, temelde ceza muhakemesi kurumu olmakla birlikte, yargılamanın yapılmasına ve cezanın miktarına dolaylı da olsa etkisi olan hukuki kurumları, çifte karakterli (hem maddi ceza hukuku hem de ceza muhakemesi hukuku niteliği olan) kurumlar olarak kabul etmektedir. Buna bağlı olarak (şikayet, izin, HAGB gibi) bu tür kurumlara ilişkin hükümlerin zaman bakımından uygulanmasında ise lehe kanun uygulaması yapılacağına hükmetmektedir. CMK geçici m. 5/1/d'de şu hükme yer verilmiştir; "1/1/2020 tarihi itibarıyla kovuşturma evresine geçilmiş, hükme bağlanmış veya kesinleşmiş dosyalarda seri muhakeme usulü ile basit yargılama usulü uygulanmaz." Oysa çifte karakterli kurumlarda lehe kanun uygulaması gereği, seri muhakeme usulünün de (tıpkı basit yargılama gibi ) CMK m.250 yürürlüğe girdikten 
sonra, kapsamında yer alan ve kesin hükme bağlanmamıș tüm uyuşmazlıklar bakımından uygulanmas1 gerekir (Bkz. TCK m.7/2). 


\section{KAYNAKÇA}

ALDEMIR, Hüsnü, Ceza Yargılamasında Seri Muhakeme ve Basit Yargılama Usulleri, Adalet Yayınevi, Ankara, 2019.

Avrupa Konseyi-Avrupa İnsan Hakları Mahkemesi Ortak Yayını, 6. Madde Rehberi-Adil Yargılanma Hakkı (Ceza Hukuku Yönü), Ankara, 2014.

BAYTAZ, Abdullah Batuhan, "Seri Muhakeme Usulü”, Ceza Hukuku ve Kriminoloji Dergisi, Y11: 2020, Cilt: 8, Say1: 2, (s. $1-47)$.

CENGIZ, Serkan / DEMIRAĞ, Fahrettin / ERGÜL, Teoman, vd., Avrupa İnsan Hakları Mahkemesi Kararları Işığında Ceza Yargılaması Kurum ve Kavramları, Türkiye Barolar Birliği ve Avrupa Konseyi Yayını, Şen Matbaa, Ankara, 2008.

CENTEL, Nur / ZAFER, Hamide, Ceza Muhakemesi Hukuku, Beta Yayınevi, İstanbul, 2020.

ÇALIŞKAN, Suat, Ceza Muhakemesinde Seri Muhakeme Usulü, https://www.hukukihaber.net/ceza-muhakemesinde-seri-muhakeme-usulumakale, 7314.html (erişim tarihi 27.08.2020).

DEĞİRMENCİ, Olgun, "Ceza Muhakemesi Hukukunda Seri Muhakeme Usulü”, Ankara Batı Adliyesi Dergisi, Y11:2020, Say1: Ocak-Haziran, (s. 16 - 22).

DONAY, Süheyl, İnsan Hakları Açısından Sanığın Hakları ve Türk Hukuku, İstanbul Üniversitesi Hukuk Fakültesi Yayınları, İstanbul, 1982.

DÖNMEZER, Sulhi / YENISEY, Feridun, Ceza Muhakemesi Hukuku, Beta Yayınevi, İstanbul, 2000.

DÖNMEZER, Sulhi, “Ceza Adaleti Sistemimiz Üzerine Düşünceler”, Yeni Türkiye Dergisi Yargı Reformu Özel Sayısı, , Yı1: 1996, Cilt: 10 Sayı: 2, (s. 553 - 560).

ECKSTEIN, Ken, “StPO § 407 Zulässigkeit”, Münchener Kommentar zur StPO Band 3 (der. C. Knauer, vd.), C. H. Beck, München, 2019.

ERDEM, Mustafa Ruhan / ŞENTÜRK, Candide, "Ceza Muhakemesi Hukukunda Yeni Bir Kurum Olarak Seri Muhakeme Yöntemi”, Ceza Hukuku Dergisi, Y11: 2019, Cilt: 14, Sayı, $41,($ s. $573-601)$.

ERSOY, Uğur, "Seri Muhakeme ve Basit Yargılama Usullerinde İtiraz Kurumuna İlişkin Sorunlar ve Çözüm Önerileri”, Selçuk Üniversitesi Hukuk Fakültesi Dergisi, Y11: 2020, Cilt: 28, Say1: 2, (s. $857-885$ ).

ESHELBACH, Andreas Grube, "StPO § 257c Verständigung zwischen Gericht und Verfahrensbeteiligten", BeckOK StPO mit RiStBV und MiStra (der. J. Graf), C.H. Beck, München, 2020.

GÖKCEN, Ahmet / BALCI, Murat / ALŞAHIN, M. Emin, vd., Ceza Muhakemesi Hukuku, Adalet Yayınevi, Ankara, 2020. 
HEINRICH, Bernd, "Rechtsstaatliche Mindestgarantien im Strafverfahren", Juristische Ausbildung, Y11: 2003, Cilt: 35, Say1: 3, (s. 167 - 173).

KATOĞLU, Tuğrul, Ceza Kanunlarının Zaman Yönünden Uygulanması, Seçkin Yayınevi, Ankara, 2008.

KEZER, Ahmet, 30 Soru ve Yanıtta Seri Muhakeme Usulü ve Basit Yargılama Usulü, Adalet Yayınevi, Ankara, 2019.

KIZILARSLAN, Hakan, “7188 Say1lı Kanun'la Ceza Muhakemesi Hukukuna Getirilen Seri Muhakeme ve Basit Yargılama Usulleri”, Bahçeşehir Üniversitesi Hukuk Fakültesi Dergisi, Y1l: 2019, Cilt: 14, Say1:183 - 184, (s. 1885 - 1960).

LADEWİG, Hans-Meyer, “Adil Yargılanma Hakkı-II", Adil Yargılanma Hakkı ve Ceza Hukuku, (çev. H. Hakeri), Seçkin Yayınevi, Ankara, 2004.

OKTAR, Salih, Seri Muhakeme ve Basit Yargılama Usulleri, 10 Aralık İnsan Hakları Günü Etkinlikleri Kapsamında Yargı Reformu Stratejisinin Değerlendirilmesi, Türkiye Barolar Birliği İnsan Hakları Merkezi Sempozyumunda Yapılan Sunum. https://www.youtube.com/watch?v=65eTxyXAaZY (erişim tarihi 20.08.2020).

ÖZBEK, Mustafa, "Dünya Çapındaki Adalete Ulaşma Hareketleriyle Gelişmeler ve Alternatif Uyuşmazlık Çözümü”, Ankara Üniversitesi Hukuk Fakültesi Dergisi, Y11: 2002, Cilt: 51, Say1: 2, (s. 121 - 162).

ÖZBEK, Veli Özer / MERAKLI, Serkan, "Hükmün Açıklanmasının Geri Bırakılması Kararına İtiraz Üzerine Yapılacak Denetim, Marmara Üniversitesi Hukuk Araştırmaları Dergisi, Y11: 2013, Cilt: 19, Say1: 2, (s. $221-236$ ).

SCHROEDER, Friedrich-Christian, "Ceza Muhakemesinde Fair Trial İlkesi”, Ceza Muhakemesinde Fair Trial İlkesi, İstanbul Barosu Yayını, İstanbul, 1999.

SELÇUK, Sami, "Doğru terim "MUHAKEME" değil, "YARGILAMA"dır", Marmara Üniversitesi Hukuk Araştırmaları Dergisi, Yı1: 2013, Cilt: 19, Sayı: 2, 2013, (s. 295 317).

ŞAHIN, Cumhur / GÖKTÜRK, Neslihan, Ceza Muhakemesi Hukuku II, Seçkin Yayınevi, Ankara, 2020.

TAŞKIN, Ş. Cankat, Ceza Muhakemesi Hukukunda Seri Muhakeme ve Basit Yargılama Usulü, Adalet Yayınevi, Ankara, 2020.

TEMMING, Dieter, "Verfahren bei Strafbefehlen", BeckOK StPO mit RiStBV und MiStra (der. J. Graf), C.H. Beck, München, 2020.

TOROSLU, Nevzat, "Ceza Yargılamalarının Çabuklaştırılması Sorunu”, Yeni Türkiye Dergisi Yargı Reformu Özel Sayısı,, Y11: 1996, Cilt: 10 Sayı: 2, (s. 613 - 615).

UĞURLUBAY, Gülsün A. Aygörmez / HAYDAR, Nuran / KORKMAZ, Mehmet, "Seri Muhakeme Usulüne İlişkin Sorunlar", Ankara Sosyal Bilimler Üniversitesi Hukuk Fakültesi Dergisi, Y11: 2019, Cilt: 1, Say1: 2, (s. 255 - 306). 
Uluslararası Af Örgütü, Adil Yargılanma Hakkı, İletişim Yayınları, İstanbul, 2000.

YAVUZ, Hakan A., Ceza Muhakemesinde Kovuşturmaya Alternatif Yöntemler, Adalet Yayınevi, Ankara, 2020.

YENISEY, Feridun / NUHOĞLU, Ayşe, Ceza Muhakemesi Hukuku, Seçkin Yayınevi, Ankara, 2020.

YENISEY, Feridun, "Ceza Adaleti Sisteminin Etkinliği, Normal Çalışma Süresi ve Gecikme", Yeni Türkiye Dergisi Yargı Reformu Özel Sayısı, Y11: 1996, Cilt: 10 Sayı: 2, (s. 574 580).

YILMAZ, Zahit / APİŞ, Özge, "Seri Muhakeme ve Basit Yargılama Düzenlemelerinin Değerlendirilmesi”, Marmara Üniversitesi Hukuk Fakültesi Hukuk Araştırmaları Dergisi, Y1l: 2020, Cilt: 26 Say1: 1, (s. 62 - 106).

YURTCAN, Erdener, Ceza Yargılaması Hukuku, Seçkin Yayınevi, Ankara, 2019. 